\title{
Holocene eruptive history of Ksudach volcanic massif, South Kamchatka: evolution of a large magmatic chamber
}

\author{
O.N. Volynets ${ }^{\mathrm{a}, 1}$, V.V. Ponomareva ${ }^{\mathrm{a}, *}$, O.A. Braitseva ${ }^{\mathrm{a}}$, I.V. Melekestsev ${ }^{\mathrm{a}}$, \\ Ch.H. Chen ${ }^{b}$ \\ a Institute of Volcanic Geology and Geochemistry, Piip Blvd. 9, Petropavlovsk-Kamchatsky 683006, Russian Federation \\ ${ }^{\mathrm{b}}$ Institute of Earth Sciences, Academia Sinica, P.O. Box 1-55 Nankang, Taipei 11529, Taiwan
}

Received 26 October 1998; received in revised form 30 March 1999; accepted 1 April 1999

\begin{abstract}
The combination of geological, tephrochronological and geochemical studies is used to reconstruct the Holocene eruptive history of Ksudach volcanic massif, South Kamchatka and to trace the evolution of its magma. Ksudach is located in the frontal volcanic zone of Kamchatka. From Early Holocene till AD 240, the volcano had repetitive voluminous caldera-forming eruptions. Later they gave way to frequent moderate explosive-effusive eruptions that formed the Shtyubel' stratovolcano inside the nested calderas, and then to frequent larger explosive eruptions. Holocene eruptive products are low- $\mathrm{K}_{2} \mathrm{O}$ two pyroxene-plagioclase basaltic andesite to rhyodacite. Mineralogical, geochemical and isotopic data suggest that all the rock varieties originated as a result of fractionation of an initial mafic melt, with insignificant contamination and assimilation. Intensive mixing of the fractionating melts prior to, and during the course of the eruptions, is ubiquitous. The eruptions might have been triggered by repetitive injections of new mafic melt into the silicic chamber. Crystallization of the andesitic and rhyodacitic melts is estimated to have occurred at temperatures of $970-1010^{\circ} \mathrm{C}$ and $890-910^{\circ} \mathrm{C}$, respectively, $P_{\mathrm{H}_{2} \mathrm{O}} 1.5-2.0 \mathrm{kbar}$ and $f_{\mathrm{O}_{2}}$ close to the NNO buffer. According to the experimental data, such $P_{\mathrm{H}_{2} \mathrm{O}}$ corresponds to $4.5 \%-5.5 \%$ of water in the melt, that is close to the content of water in the silicic hornblende-bearing magmas of the rear zone of the Kuril-Kamchatka arc. Hence, we suggest that the transition from pyroxene phenocryst associations of the frontal zone to the hornblende-bearing ones of the rear zone might be interpreted as reflecting higher temperatures of crystallization of the melts from the frontal zone rather than increasing water content in the rear zone magmas. (C) 1999 Elsevier Science B.V. All rights reserved.
\end{abstract}

Keywords: Kamchatka; caldera; volcano; eruptive history; Holocene; geochemistry of volcanic rocks

\section{Introduction}

Eruptions which result in the formation of Krakatau-type calderas are one of the most haz-

\footnotetext{
* Corresponding author. E-mail: ponomareva@geo.tv-sign.ru; ponomareva@ginran.msk.su

${ }^{1}$ Deceased 24 October 1998.
}

ardous natural events and can have profound environmental impact due to production of voluminous tephra. At the same time they provide data for speculations on the endogenic processes which favour the formation of the large amounts of silicic magma and trigger powerful eruptions. Five Krakatau-type calderas formed in Kamchatka during the last 10000 years (Braitseva et al., 1995), three of them in the 
Ksudach volcanic massif, located in the frontal volcanic zone of the island arc (Fig. 1). Tephras from the caldera-forming eruptions of Ksudach are low$\mathrm{K}_{2} \mathrm{O}$ two-pyroxene-plagioclase andesite to rhyodacite with volumes ranging from 1.5 to $19 \mathrm{~km}^{3}$ (Braitseva et al., 1996; Melekestsev et al., 1996). The most recent caldera encloses a stratovolcano named Shtyubel' Cone, which erupted basaltic andesite to rhyodacite, with eruption volumes of up to
$2 \mathrm{~km}^{3}$ (Melekestsev et al., 1996; Braitseva et al., 1997b). Ksudach tephra contains both silicic and mafic pumice in the same units, and abundant taxitic pumice varieties with alternating silicic and mafic bands, that suggests the intensive mixing of the melts in the course of the Ksudach eruptions (Volynets, 1979). Tephra layers, interbedded with soils and ash horizons from other Kamchatka volcanoes, provide a continuous record of the Holocene explosive activity

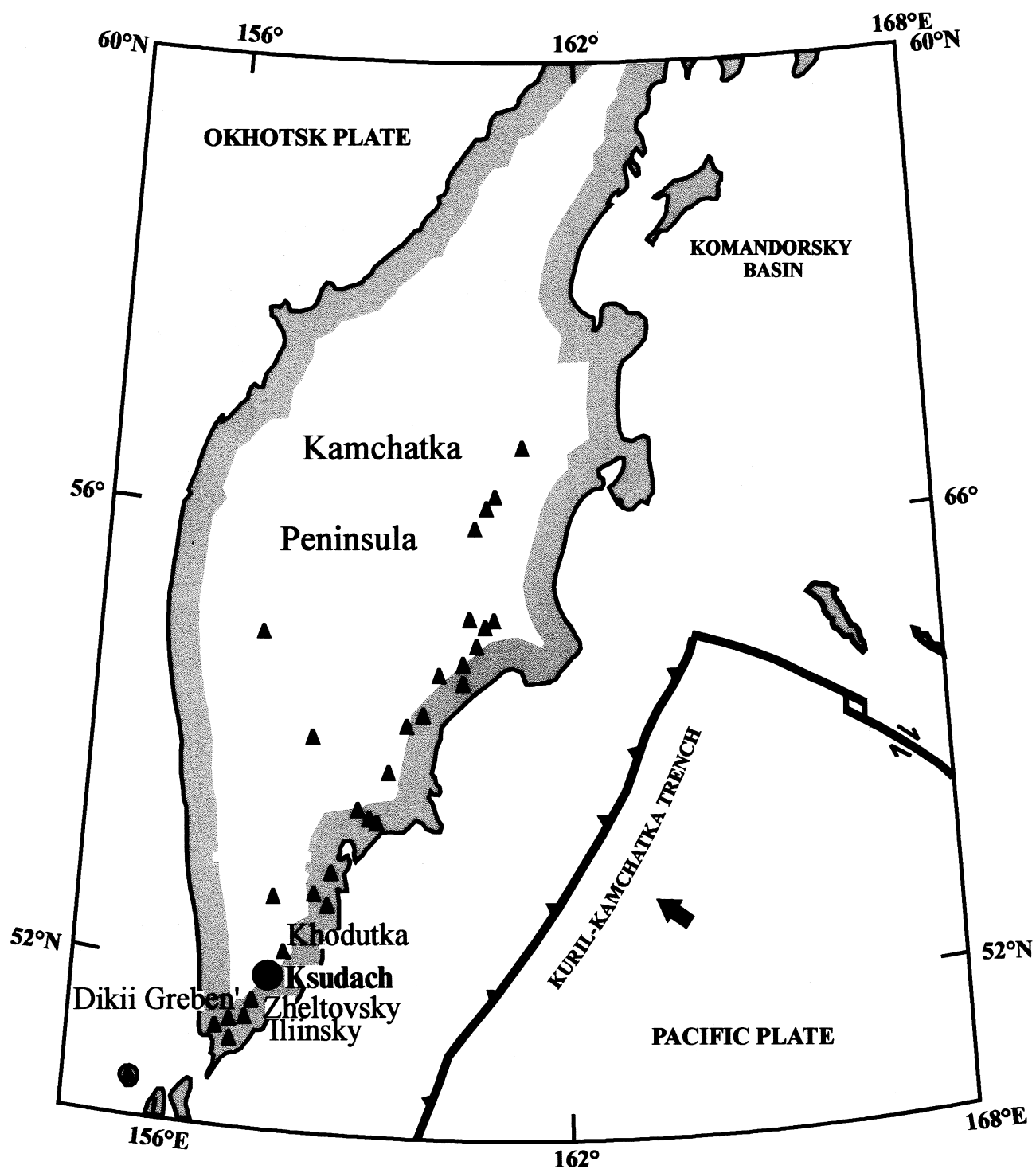

Fig. 1. Location of the Ksudach volcanic massif (black circle). Other active volcanoes are shown with black triangles. 
of Ksudach and allow to reconstruct its eruptive history for the last 10000 years.

Repetitive voluminous explosive eruptions and the characteristics of the tephra suggest conditions favourable for production of a large amount of silicic magma beneath the volcano and its periodic interaction with more mafic melt. In this paper, we combine the results of geological, tephrochronological and petrochemical studies to explain characteristic features of the Ksudach melts, reveal the mechanism of the Ksudach volcanic rocks formation, and trace their evolution during the Holocene.

\section{Holocene eruptive history of Ksudach volcano}

Ksudach volcanic massif is a shield-like polygenetic edifice composed of lavas and tephra of multiple eruptive centers of various age and morphology. It comprises nested calderas which formed during five collapse events (Figs. 2 and 3). Two larger calderas (I and II) formed in the Late Pleistocene time and three smaller ones (III, IV and V) during the Holocene (Braitseva et al., 1995; Melekestsev et al., 1996). Caldera V encloses an active stratovolcano named Shtyubel' Cone; its most recent eruption occurred in 1907 (Hulten, 1924; Vlodavets and Piip, 1957). The pyroclastic deposits of the largest Holocene eruptions are tens to hundreds of meters thick near the vent (Fig. 4) and form layers which can be traced over much of the Kamchatka Peninsula (Braitseva et al., 1992, 1997b). Several minor eruptions produced ashfalls of negligible volumes (about $0.01 \mathrm{~km}^{3}$ ) compared to these of the larger eruptions; some of them might have been associated with the post-caldera extrusive domes growth. Detailed geological and tephrochronological studies combined with radiocarbon dating have allowed us to reconstruct the Holocene eruptive history of Ksudach volcano (Figs. 5 and 6). Pre-Holocene ash layers were mostly destroyed during Late Pleistocene glaciation, hampering detailed studies of the early volcanic activity. The following summary of the Holocene activity of Ksudach is based on the works of Braitseva et al. (1996) and Melekestsev et al. (1996) supplemented by new data. The ages of Ksudach eruptions are refined according to Braitseva et al. (1997a,b).
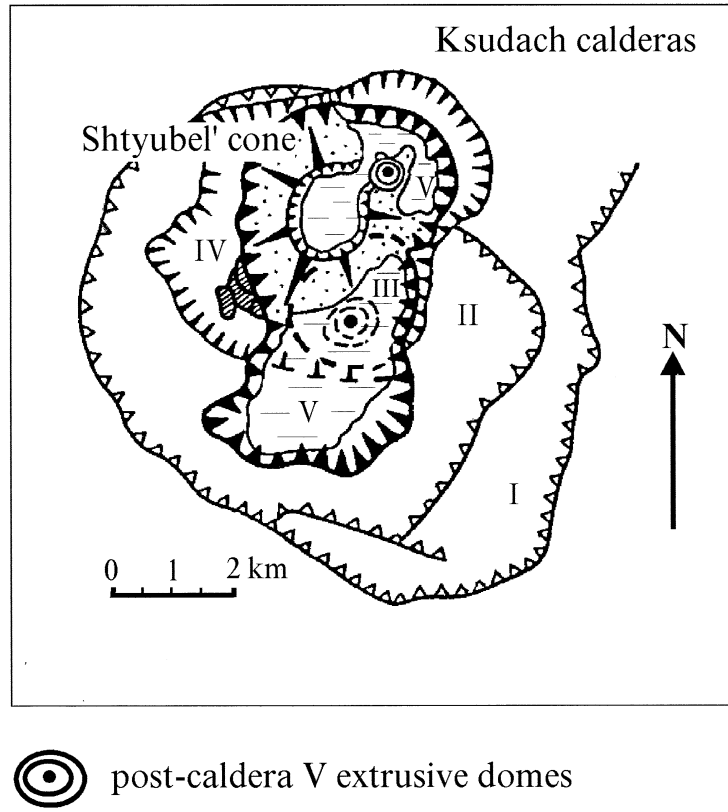

post-caldera $\mathrm{V}$ extrusive domes

$$
\oslash \text { post-caldera IV extrusive domes }
$$

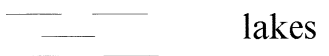

Fig. 2. Calderas of the Ksudach volcanic massif. The rims of the calderas are shown by various toothed lines. Calderas are numbered by Roman numerals: I and II-Late Pleistocene calderas; III, IV and V-Holocene ones. Caldera V encloses Shtyubel' Cone. Submerged features are shown by dashed lines.

The codes of the eruptions and calderas are as in the works of Braitseva et al. (1996, 1997b). We report both radiocarbon (Fig. 5) and calendar (Fig. 6) ages of the eruptions. Radiocarbon ages are cited as ${ }^{14} \mathrm{C}$ years BP, and calibrated ages - as years BC or AD. The calendar ages were obtained using the technique by Stuiver and Reimer (1993). Calendar ages are also used throughout the text to estimate the real duration of active and repose periods.

Caldera III was formed about BC 7900 as a result of the $\mathrm{KS}_{4}$ eruption. This eruption was preceded by a period of relative quiescence which is likely to have continued for at least 1-1.5 thousand years, since no Ksudach tephra layers are registered in the soil interlayered between Late Pleistocene glacial deposits and $\mathrm{KS}_{4}$ tephra. The deposits of the $\mathrm{KS}_{4}$ eruption include several tephra fall units, alternating 


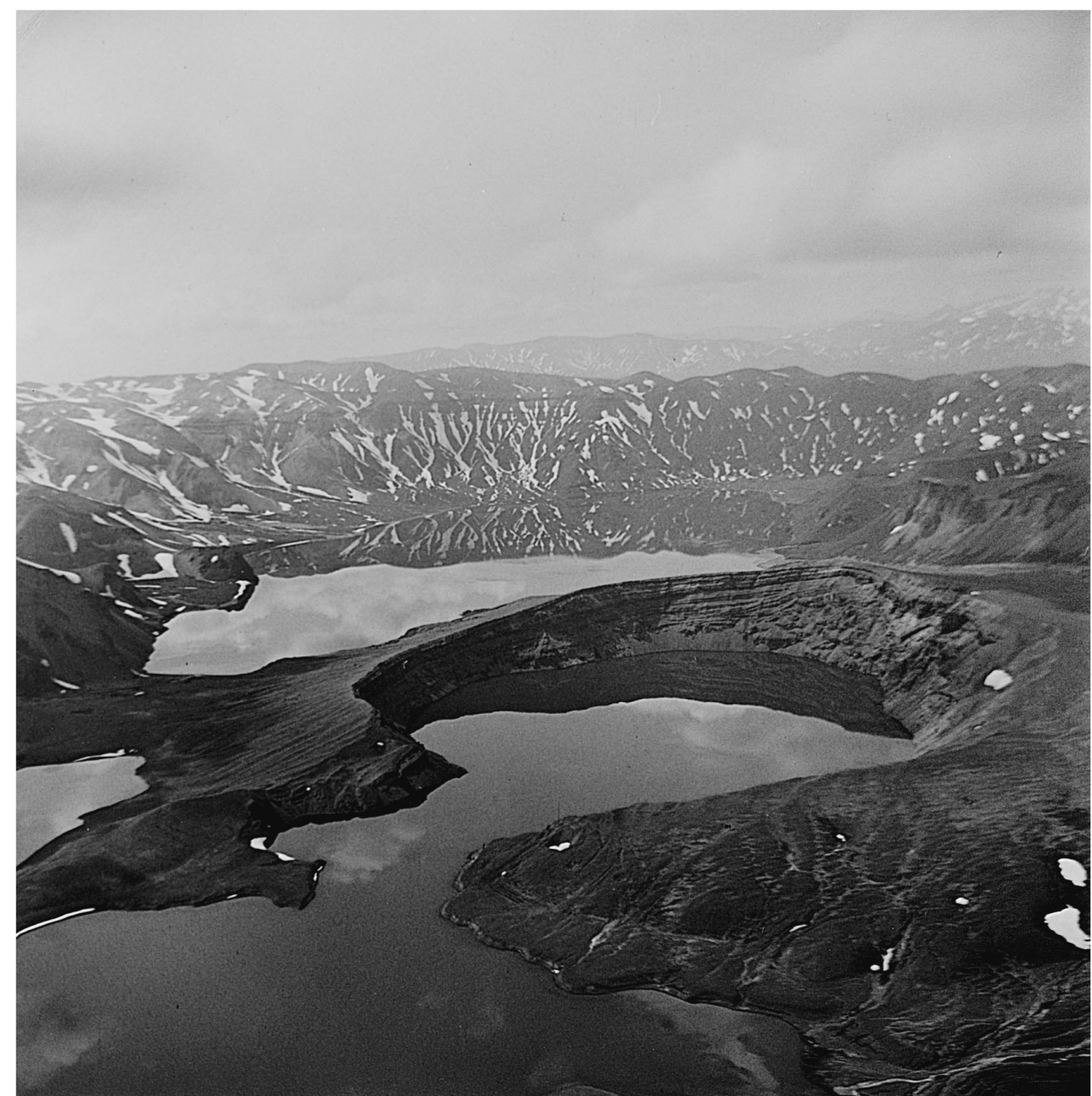

Fig. 3. Ksudach volcanic massif viewed from the northeast. Photo by A.A. Razina.

with pyroclastic surge beds and explosion breccia, capped with a pyroclastic flow unit (Fig. 5). Total volume of juvenile tephra is estimated at $1.5-2 \mathrm{~km}^{3}$ (about $0.8 \mathrm{~km}^{3} \quad$ DRE-dense rock equivalent) (Melekestsev et al., 1996). Fall deposits are represented by stratified, black or light-brown pumice bombs and lapilli. Initial fall unit contains the most silicic (rhyodacitic) pumice bombs (Fig. 5; Table 1, analysis 4) while later products are dominantly andesites and dacites. Black andesitic and light-brown dacitic pumice bombs as well as occasional banded varieties occur in the same layer. Near the vent black andesitic bombs are occasionally welded (Selyangin, 1990).
Caldera IV formed as a result of two closely spaced in time large eruptions $\mathrm{KS}_{3}$ and $\mathrm{KS}_{2}$ (Figs. 5 and 6). The earlier $\mathrm{KS}_{3}$ eruption was previously dated at about $6100{ }^{14} \mathrm{C}$ years BP (about BC 5000) (Braitseva et al., 1997b). However, new radiocarbon dates $(6300 \pm 90$ and $6210 \pm 100$ from above the $\mathrm{KS}_{3}$ layer and $6380 \pm 40$ from under it) suggest an age of about $6300{ }^{14} \mathrm{C}$ years BP (about BC 5200). Then the repose period between $\mathrm{KS}_{4}$ and $\mathrm{KS}_{3}$ eruptions was about 2700 years. During this period one minor eruption produced a moderate volume of gray andesitic tephra (Fig. 6). Both large eruptions $\left(\mathrm{KS}_{3}\right.$ and $\mathrm{KS}_{2}$ ) produced explosion breccias, pyroclastic flows and falls. $\mathrm{KS}_{3}$ juvenile deposits contain mainly 


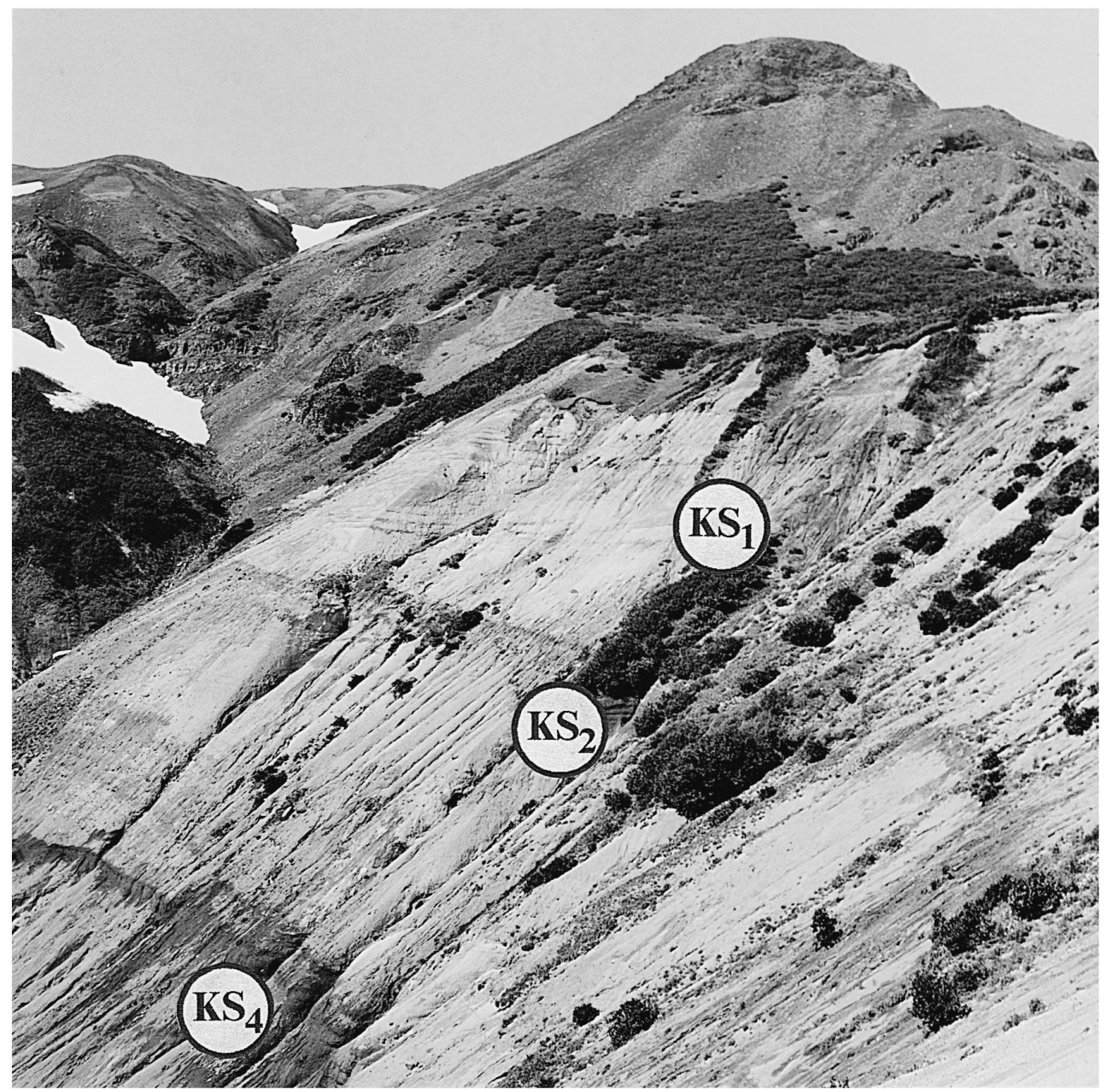

Fig. 4. Pyroclastic products of the Holocene eruptions of Ksudach exposed inside the caldera complex. The height of the exposure is about $100 \mathrm{~m}$. For codes of the pyroclastic units see Fig. 5. Photo by L.D. Sulerzhitsky.

white rhyodacitic and yellowish dacitic pumice with only a minor admixture of black andesitic lapilli (Table 1). The products of the final stage of the eruption tend to be more homogenous in composition than those of the initial one and correspond to dacite (Fig. 5).

$\mathrm{KS}_{2}$ fall deposits are represented by a thick unit of gray, dark-gray and violet finely banded pumice bombs which are occasionally welded (Selyangin, 1990). The bulk composition of $\mathrm{KS}_{2}$ tephra was uniformly andesitic throughout the eruption (Table 1,
Fig. 5). Eucrite and allivalite xenoliths are abundant (Volynets et al., 1978; Braitseva et al., 1992).

Total volume of tephra of both large eruptions $\left(\mathrm{KS}_{2}\right.$ and $\mathrm{KS}_{3}$ ) is estimated at about $10-11 \mathrm{~km}^{3}$ (or $4.7 \mathrm{~km}^{3}$ DRE) most of which $(70 \%-80 \%)$ is presented by $\mathrm{KS}_{2}$ eruption products (Melekestsev et al., 1996). We cannot estimate the volumes of the rocks of different composition separately but andesite obviously predominates. The formation of caldera IV was followed by the growth of a series of dacitic extrusive domes with a total volume of about 


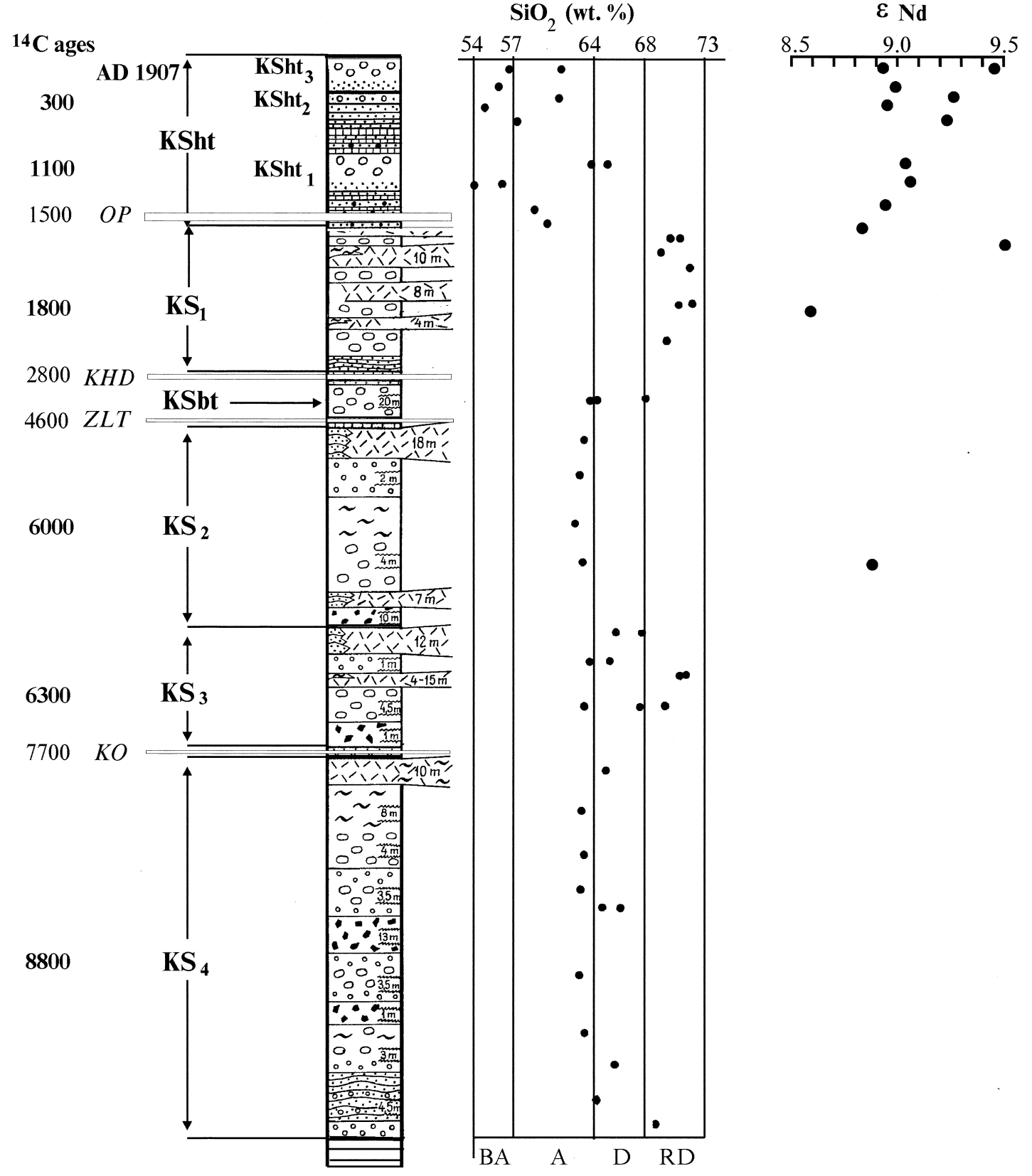

Fall deposits:

00 pumice bombs and lapilli

$\sim$ welded bombs

$\cdots$ coarse ash
Flow and surge deposits:

$\ulcorner\approx$ tuff, occasionally welded

…… stratified coarse ash

$\sim$ fine ash $\square$ explosion breccia

$\equiv$ lacustrine deposits

- buried soil marker ash layers 
$0.5 \mathrm{~km}^{3}$ (Fig. 2). Minor explosive eruption which occurred somewhat later the $\mathrm{KS}_{2}$ eruption might have been associated with these domes growth. Since the volume of the domes ranks far below that of $\mathrm{KS}_{3}$ and $\mathrm{KS}_{2}$ pyroclastic deposits the period following the $\mathrm{KS}_{2}$ eruption might be considered as a period of relative quiescence (Fig. 6).

The next large eruption $\left(\mathrm{KS}_{\mathrm{bt}}\right)$ produced about $0.5 \mathrm{~km}^{3}$ of fall deposit, called the 'bomb tuff', because it is dominated by large bombs of andesitic and dacitic pumice. This eruption occurred about BC 3000, after 1900 years of quiescence. The $\mathrm{KS}_{\mathrm{bt}}$ tephra is bracketed stratigraphically between the tephra marker horizons of Khodutkinsky maar (KHD, about BC 900) and Iliinsky (ZLT, about BC 3400) volcanoes and lies closer to the latter (Fig. 5).

The youngest caldera-forming (caldera V) eruption $\mathrm{KS}_{1}$, took place about $\mathrm{AD} 240$ and was separated from the $\mathrm{KS}_{\mathrm{bt}}$ eruption by approximately a 3200-year interval during which only one minor eruption can be identified (Fig. 6). The $\mathrm{KS}_{1}$ eruption was the second largest Holocene eruption in Kamchatka, after the formation of the Kurile Lake caldera, and was similar in type and characteristics to the 1883 Krakatau eruption (Braitseva et al., 1996). The $\mathrm{KS}_{1}$ eruption produced about $18-19 \mathrm{~km}^{3}\left(8 \mathrm{~km}^{3}\right.$ DRE) of tephra. Proximal tephra-fall deposits are pumice lapilli and bombs. At least four bomb beds are identified, each underlying pyroclastic-flow deposits. Pumices of the lower three beds are white or yellow and those of the upper bed are blue-gray. Both white and gray pumice bombs and lapilli are rhyodacites (Table 1, Fig. 5). The $\mathrm{KS}_{1}$ ash retains the two-color structure downwind at a distance of at least $650 \mathrm{~km}$ (Braitseva et al., 1996). Different color of pumice might be related to the size and distribution of $\mathrm{Fe}^{3+}$-rich oxide microcrysts (Paulick and Franz, 1997) and may indicate a change in the eruption dynamics. The $\mathrm{KS}_{1}$ eruption produced the largest amount of rhyodacitic material of all the Holocene Ksudach eruptions and no admixture of more mafic material, so typical for tephra of other larger eruptions, have ever been reported.

Shtyubel' Cone began to grow within caldera V about a hundred years after caldera V collapsed, as the first layer of its andesitic tephra is separated from the $\mathrm{KS}_{1}$ deposits by only a thin paleosol. All subsequent eruptions from Ksudach, including the historically recorded one in $1907\left(\mathrm{KSht}_{3}\right)$, originated from Shtyubel' Cone and were separated by quiescence periods less than a few hundred years (Fig. 6). The formation of Shtyubel' Cone began from moderate explosive eruptions and extrusion of lavas. Later it gave three large explosive eruptions $\left(\mathrm{KSht}_{1}, \mathrm{KSht}_{2}\right.$, $\mathrm{KSht}_{3}$ ) with eruption volumes up to $2 \mathrm{~km}^{3}$. The products of Shtyubel' Cone range from basaltic andesites to dacite and rhyodacite (Table 1, Fig. 5). Only during the lifetime of Shtyubel' Cone did the basaltic andesitic material come to the surface and lava flows form.

Fall deposits of the larger eruptions $\left(\mathrm{KSht}_{1}\right.$, $\mathrm{KSht}_{2}, \mathrm{KSht}_{3}$ ) are heterogeneous and consist of at least two subunits. The lower subunit is composed of black scoria bombs and lapilli of basaltic andesite whereas the upper subunit comprises white, pink and yellow dacitic to rhyolitic pumice bombs sometimes (in $\mathrm{KSht}_{2}$ and $\mathrm{KSht}_{3}$ tephras) with an admixture of more mafic ones. Macias and Sheridan (1995) describe the still more complicated stratification of the 1907 fall deposits with few alternating black and light layers. Bursik et al. (1993) stated that although the scoriaceous subunit comprises a variable fraction of the stratigraphic section for each deposit (up to $50 \%$ in $\mathrm{KSht}_{1}$ ), in no case does it comprise a significant volume itself, because of its local dispersal. Nevertheless our recent field studies in South Kamchatka demonstrated that the layer of the $\mathrm{KSht}_{1}$ tephra retains its two-subunits structure as far as

Fig. 5. Summary section through the Holocene pyroclastic deposits of Ksudach volcano. Marker ash layers useful for the Ksudach stratigraphy are (from top to bottom): OP from Baraniy Amfiteatr crater, at the foot of Opala volcano; KHD from Khodutkinsky Maar; ZLT from Iliinsky volcano; KO from the Kurile Lake caldera. Codes and radiocarbon ages of the ash layers according to Braitseva et al. (1997a,b) (ages are rounded to the nearest hundred). The age of $\mathrm{KS}_{3}$ tephra refined by the authors (see the text). Silica content and $\varepsilon$ Nd variations are shown to the right of the section; reproducibility $(2 \sigma)= \pm 0.3 \varepsilon \mathrm{Nd}$. BA, A, D, RD-basaltic andesite, andesite, dacite and rhyodacite, correspondingly. 


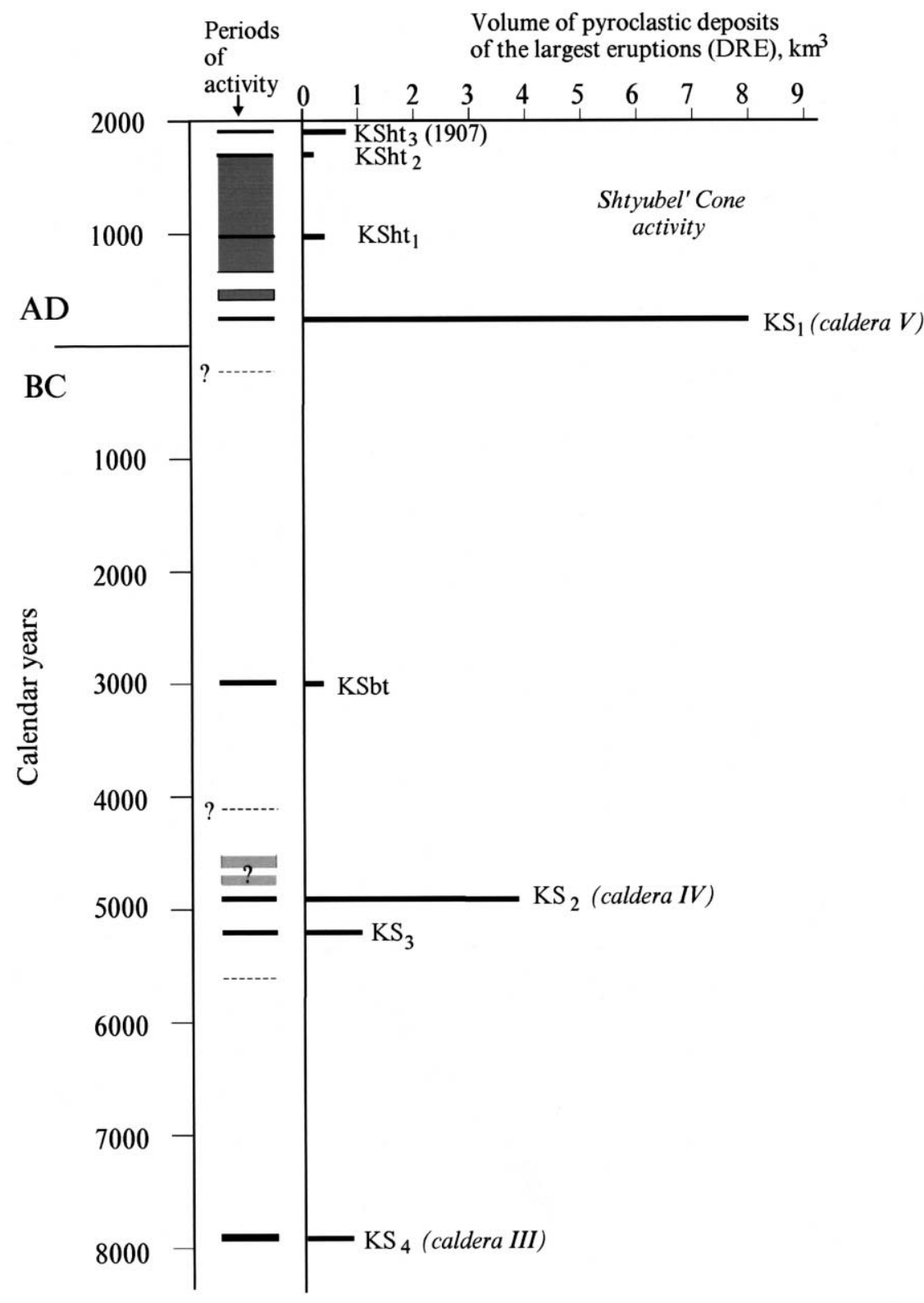

Volcanic activity:

Fig. 6. Holocene eruptive history of Ksudach volcanic massif. Calendar ages are given according to Braitseva et al. (1997a). Dense rock equivalent (DRE) volumes according to Melekestsev et al. (1996). Question marks near minor eruptions indicate uncertainty in determination of their ages. Other captions as in Fig. 5.

southern slopes of Kambalny volcano, a distance of $60-70 \mathrm{~km}$ from the source. So the volume of basaltic andesitic scoria of the lower subunit of $\mathrm{KSht}_{1}$ eruption can be estimated at least $0.05 \mathrm{~km}^{3}$ while the 
Table 1

Representative major element analyses for the Holocene erupted products of the Ksudach volcanic massif

\begin{tabular}{|c|c|c|c|c|c|c|c|c|c|c|c|c|c|c|c|c|}
\hline & \multicolumn{4}{|l|}{$\mathrm{KS}_{4}$} & \multicolumn{3}{|l|}{$\mathrm{KS}_{3}$} & \multicolumn{2}{|l|}{$\mathrm{KS}_{2}$} & \multirow{2}{*}{$\frac{\mathrm{KS}_{\mathrm{bt}}}{10}$} & \multicolumn{2}{|l|}{$\mathrm{KS}_{1}$} & \multicolumn{4}{|c|}{ Shtyubel' volcano } \\
\hline & 1 & 2 & 3 & 4 & 5 & 6 & 7 & 8 & 9 & & 11 & 12 & 13 & 14 & 15 & 16 \\
\hline $\mathrm{SiO}_{2}$ & 62.48 & 65.78 & 64.69 & 68.78 & 62.80 & 69.56 & 71.32 & 62.57 & 63.10 & 63.66 & 71.78 & 70.09 & 53.27 & 56.74 & 64.09 & 68.45 \\
\hline $\mathrm{Al}_{2} \mathrm{O}_{3}$ & 16.31 & 15.67 & 15.79 & 15.25 & 16.19 & 15.49 & 14.67 & 16.51 & 16.45 & 16.32 & 14.68 & 15.08 & 17.18 & 15.76 & 15.51 & 16.16 \\
\hline $\mathrm{Fe}_{2} \mathrm{O}_{3}$ & 3.76 & 1.76 & 0.69 & 1.24 & 2.82 & 0.79 & 0.76 & 2.76 & 2.26 & 1.93 & 0.59 & 0.55 & 10.44 & 4.42 & 2.71 & 1.44 \\
\hline $\mathrm{FeO}$ & 3.47 & 3.88 & 4.29 & 3.59 & 4.60 & 3.64 & 3.18 & 3.99 & 4.46 & 3.81 & 2.53 & 3.24 & - & 5.64 & 4.10 & 3.38 \\
\hline $\mathrm{CaO}$ & 5.23 & 4.22 & 5.22 & 3.67 & 4.92 & 2.68 & 2.00 & 5.48 & 5.20 & 5.35 & 2.29 & 2.87 & 9.55 & 7.91 & 5.07 & 2.74 \\
\hline $\mathrm{Na}_{2} \mathrm{O}$ & 3.89 & 4.51 & 4.77 & 4.01 & 4.00 & 4.83 & 4.94 & 4.20 & 3.82 & 4.17 & 4.91 & 4.82 & 3.02 & 3.38 & 4.13 & 4.50 \\
\hline $\mathrm{K}_{2} \mathrm{O}$ & 1.08 & 1.22 & 1.17 & 1.51 & 1.14 & 1.51 & 1.49 & 1.15 & 1.18 & 1.09 & 1.57 & 1.41 & 0.44 & 0.78 & 1.22 & 1.48 \\
\hline $\mathrm{P}_{2} \mathrm{O}_{5}$ & 0.22 & 0.21 & 0.11 & 0.22 & 0.19 & 0.13 & 0.12 & 0.21 & 0.21 & 0.26 & 0.10 & 0.10 & 0.11 & 0.19 & 0.08 & 0.07 \\
\hline
\end{tabular}

All analyses recalculated to $100 \%$, volatile-free. Alkalis were analyzed by flame photometry, other components-by 'wet' chemical analysis. $K S_{4}$ eruption: 1 -pumice lapilli $(8963 / 15), 2$-light pumice bomb $(88151 / 4), 3$-pumice from pyroclastic flow deposits

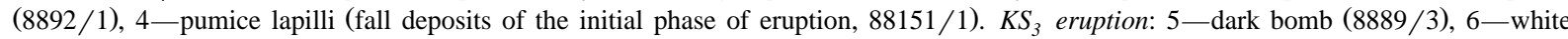
bomb $(8889 / 2$; the samples 5 and 6 are from the same layer), 7-pumice from the pyroclastic flow deposit of the initial phase of the eruption $(86039 / 19) . K S_{2}$ eruption: 8 - bomb $(8639 / 15), 9$ - pumice bomb from the pyroclastic flow deposits $(88136 / 8) . K S_{b t}$ eruption: 10-pumice lapilli $(8894 / 1) . K S_{1}$ eruption: 11 - white pumice bomb from fall deposits of the initial phase of the eruption (8880/5), 12- gray pumice bomb from the fall deposits of the final phase of the eruption (8802/2). Shtyubel' volcano eruptions: 13 -black bomb (7452), total $\mathrm{Fe}$ as $\mathrm{Fe}_{2} \mathrm{O}_{3}, 14$-black cinder lapilli from the lower subunit of the $\mathrm{KSht}_{1}$ deposits (8960/2), 15-white pumice bomb from the upper subunit of the KSht ${ }_{1}$ deposits (8960/1), 16- pumice bomb of $\mathrm{KSht}_{3}$ (1907 AD) eruption (8825/1). Figures in parentheses are the original numbers of samples. Samples 14, 5, 15, and 6 were used for the microprobe study of minerals composition in basaltic andesite, andesite, dacite and rhyodacite, respectively (Tables 2-5).

volume of the upper subunit-at about $1 \mathrm{~km}^{3}$ (Melekestsev et al., 1996). Pumiceous subunits of these eruptions are rich in eucrite and allivalite xenoliths (Volynets et al., 1978; Selyangin, 1990; Braitseva et al., 1992).

The study of the Holocene eruptive history of Ksudach suggests that it may be subdivided into two stages. During the first stage, from Early Holocene till AD 240, the volcano produced dominantly powerful explosive eruptions separated by long (19003240 years) periods of relative quiescence. Its regime of activity changed abruptly after the collapse of caldera V and the onset of Shtyubel' Cone formation. During the second stage, the rare large explosive eruptions gave place to frequent moderate explosive-effusive cone-building eruptions, and then to frequent larger explosive eruptions. Along with this change in the regime of activity, the change in the composition of the erupted products occurred with the first eruptions of basaltic andesite material, the most mafic of all the Holocene Ksudach products (Fig. 5).
The Holocene activity of Ksudach volcano has a distinct cyclic regime. Each cycle consists of an active period followed by a period of relative quiescence. We can identify four such cycles during the last 10000 years (Fig. 6). The active period consists either of a series of eruptions which are closely spaced in time or of only one powerful eruption. The duration of active periods varies from years and hundreds of years to thousands of years, but the duration of the completed cycles equals 1900-3240 years. The current cycle is incomplete.

Volumes of the material erupted differ from cycle to cycle (Fig. 6): the most voluminous cycle is the current one which began from the caldera-forming eruption $\left(\mathrm{KS}_{1}\right)$ and continued with construction of the Shtyubel' volcano. The most recent caldera-forming eruption $\left(\mathrm{KS}_{1}\right)$ was at the same time the most voluminous and produced the largest volume of the most silicic (rhyodacitic) material without visual admixture of more mafic products. Rhyodacites of less volume were also erupted during the initial stage of the $\mathrm{KS}_{3}$ eruption, and in negligible volumes in the 
very beginning of the $\mathrm{KS}_{4}$ eruption and during the 1907 eruption (Fig. 5), but all these tephras contain more mafic pumice varieties that suggest mixing of silicic and mafic melts. Basaltic andesitic material was erupted only during Shtyubel' Cone formation alternating with dominating more silicic products. All the other tephra corresponds in bulk composition to andesite and dacite. Andesites dominate in the products erupted during $\mathrm{KS}_{4}$ and $\mathrm{KS}_{2}+\mathrm{KS}_{3}$ eruptions. Normally these are very finely banded pumices

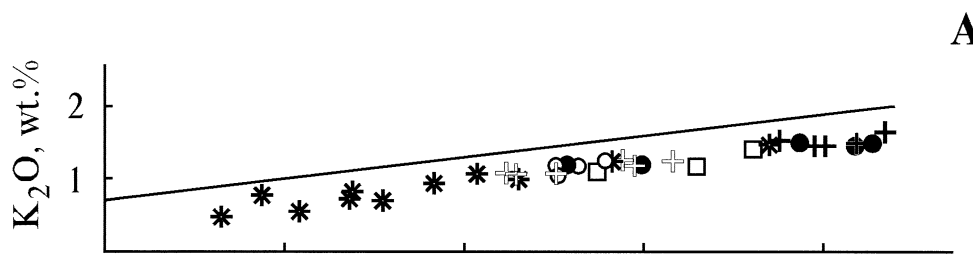

$\mathbf{A}$

B

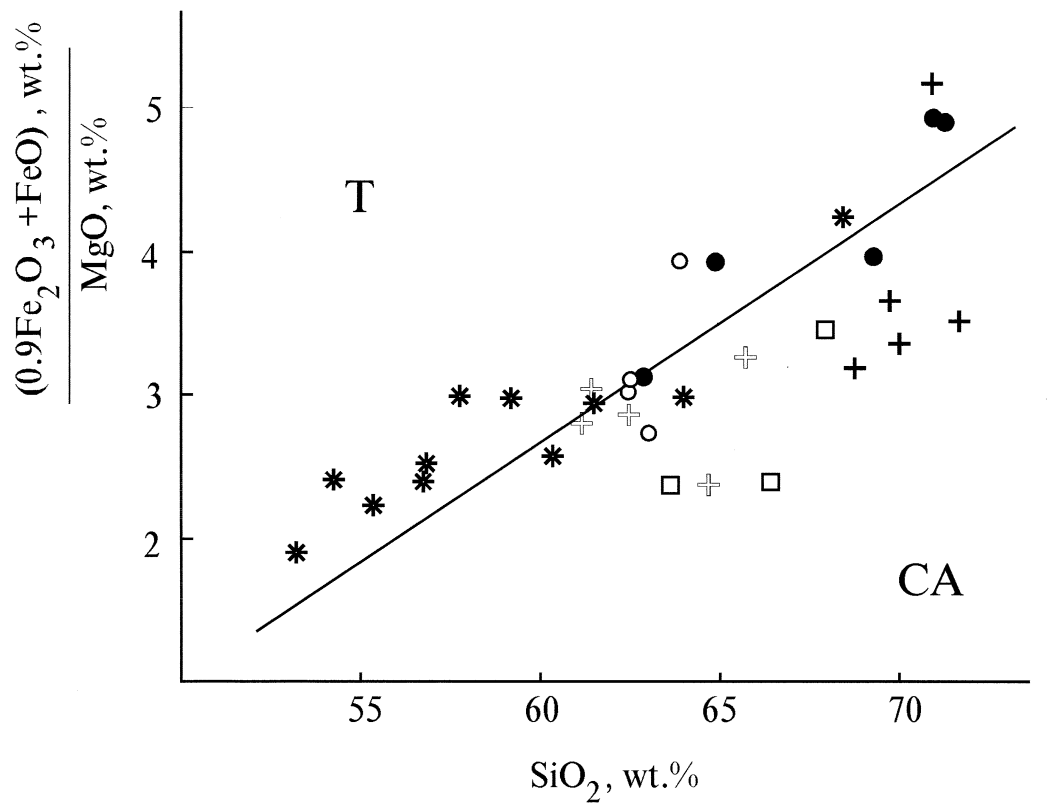

Erupted products from:

$\begin{array}{lll}* \text { Shtyubel cone } & \square \mathrm{KSbt} & \bullet \mathrm{KS}_{3} \\ +\mathrm{KS}_{1} & \circ \mathrm{KS}_{2} \Vdash \mathrm{KS}_{4}\end{array}$

Fig. 7. Classification petrochemical diagrams for the Holocene erupted products of Ksudach volcanic massif. (A) Upper boundary of the field of low-K rocks after Gill (1981). (B) Partitive line between tholeitic (T) and calc-alkaline (CA) rocks after Myashiro (1974). 
Table 2

Representative olivine and ore oxides analyses from Ksudach rocks

\begin{tabular}{|c|c|c|c|c|c|c|c|c|c|c|c|c|c|}
\hline \multirow[t]{3}{*}{ Phase } & \multicolumn{4}{|l|}{ Olivine } & \multicolumn{6}{|c|}{ Titanomagnetite } & \multicolumn{3}{|l|}{ Ilmenite } \\
\hline & \multicolumn{2}{|c|}{ Andesite } & \multicolumn{2}{|l|}{ Dacite } & \multicolumn{2}{|c|}{ Basaltic andesite } & \multirow{2}{*}{$\frac{\text { Andesite }}{\mathrm{m}}$} & \multicolumn{2}{|l|}{ Dacite } & \multirow{2}{*}{$\frac{\text { Rhyodacite }}{\mathrm{i}}$} & \multirow{2}{*}{$\frac{\text { Dacite }}{\mathrm{i}}$} & \multicolumn{2}{|c|}{ Rhyodacite } \\
\hline & $\mathrm{ph}, \mathrm{c}$ & $\mathrm{m}$ & $\mathrm{ph}, \mathrm{c}$ & $\mathrm{m}$ & $\mathrm{i}$ & $\mathrm{i}$ & & $\mathrm{i}$ & $\mathrm{i}$ & & & $\mathrm{i}$ & $\mathrm{i}$ \\
\hline $\mathrm{SiO}_{2}$ & 38.31 & 37.98 & 36.31 & 38.25 & 0.00 & 0.00 & 0.00 & 0.01 & 0.00 & 0.00 & 0.10 & 0.00 & 0.00 \\
\hline $\mathrm{TiO}_{2}$ & 0.00 & 0.00 & 0.00 & 0.00 & 5.57 & 9.27 & 14.84 & 7.62 & 17.17 & 14.28 & 46.79 & 46.77 & 46.62 \\
\hline $\mathrm{Al}_{2} \mathrm{O}_{3}$ & 0.00 & 0.00 & 0.00 & 0.00 & 6.91 & 3.40 & 2.09 & 3.93 & 1.89 & 1.83 & 0.01 & 0.03 & 0.04 \\
\hline $\mathrm{Cr}_{2} \mathrm{O}_{3}$ & 0.04 & 0.00 & 0.00 & 0.01 & 0.05 & 0.06 & 0.03 & 0.04 & 0.01 & 0.00 & 0.00 & 0.00 & 0.01 \\
\hline $\mathrm{Fe}_{2} \mathrm{O}_{3}$ & - & - & - & - & 52.12 & 49.06 & 39.13 & 50.51 & 34.25 & 39.98 & 12.20 & 12.64 & 13.11 \\
\hline $\mathrm{FeO}$ & 23.87 & 25.90 & 26.80 & 23.93 & 21.45 & 35.89 & 42.18 & 34.04 & 44.77 & 41.69 & 38.26 & 37.26 & 37.01 \\
\hline $\mathrm{MnO}$ & 0.40 & 0.50 & 0.40 & 0.43 & 0.35 & 0.45 & 0.87 & 0.46 & 0.94 & 0.82 & 1.15 & 1.27 & 1.12 \\
\hline $\mathrm{MgO}$ & 36.70 & 35.29 & 36.46 & 36.35 & 3.64 & 2.64 & 1.49 & 2.61 & 1.07 & 1.33 & 1.47 & 2.03 & 2.10 \\
\hline $\mathrm{CaO}$ & 0.15 & 0.13 & 0.17 & 0.20 & 0.06 & 0.00 & 0.06 & 0.07 & 0.00 & 0.06 & 0.03 & 0.00 & 0.00 \\
\hline Sum & 99.47 & 99.82 & 100.14 & 99.18 & 100.15 & 100.77 & 100.69 & 99.29 & 100.10 & 99.99 & 100.01 & 100.00 & 100.01 \\
\hline $\mathrm{Mg \#}$ & 0.733 & 0.708 & 0.708 & 0.730 & 0.087 & 0.056 & 0.033 & 0.055 & 0.025 & 0.030 & 0.050 & 0.069 & 0.071 \\
\hline
\end{tabular}

The following abbreviations are used for phase names here and in Tables 3-5: ph-phenocryst, $\mathrm{m}-$ microlite, mg-megacryst, gl—glass, gm-groundmass, c-phenocryst centre, i-inclusion in phenocryst. Bulk rock chemistry see in Table 1 (8960/2-basaltic andesite; 8889 /3 - andesite; $8860 / 1$ — dacite; $8889 / 2$-rhyodacite $) . \mathrm{Mg} \#=\mathrm{Mg} /(\mathrm{Mg}+\mathrm{Fe})$, in mol. Here and in Tables 3-5 analyses have been made by Cameca microprobe in the Institute of Volcanology, Petropavlovsk-Kamchatsky, Russia.

that suggest more thorough mixing of silicic and mafic melts.

\section{Composition of the erupted products}

The rocks produced by Ksudach volcano during the Holocene range from basaltic andesite to rhyo- dacite. Silicic rocks were erupted repeatedly (Fig. 5) while the more mafic basaltic andesites are restricted to the Shtyubel' Cone activity. All the Holocene erupted products are low- $\mathrm{K}_{2} \mathrm{O}$ rocks with $\mathrm{FeO}^{*} /$ $\mathrm{MgO}$ ratio intermediate between tholeitic and calcalkaline series (Fig. 7), and are similar to pre-Holocene eruptive rocks (Selyangin, 1990, 1991). The phenocryst assemblage of the Ksudach rocks com-

Table 3

Representative pyroxene analyses from Ksudach rocks

\begin{tabular}{|c|c|c|c|c|c|c|c|c|c|c|c|c|c|}
\hline \multirow[t]{2}{*}{ Phase } & \multicolumn{3}{|c|}{ Basaltic andesite } & \multicolumn{2}{|c|}{ Andesite } & \multicolumn{6}{|l|}{ Dacite } & \multicolumn{2}{|c|}{ Rhyodacite } \\
\hline & $\mathrm{i}(\mathrm{mg}), \mathrm{c}$ & $\mathrm{ph}, \mathrm{c}$ & $\mathrm{ph}, \mathrm{c}$ & $\mathrm{m}$ & $\mathrm{m}$ & $\mathrm{ph}, \mathrm{c}$ & $\mathrm{ph}, \mathrm{c}$ & $\mathrm{m}$ & $\mathrm{ph}, \mathrm{c}$ & $\mathrm{ph}, \mathrm{c}$ & $\mathrm{m}$ & $\mathrm{ph}, \mathrm{c}$ & $\mathrm{ph}, \mathrm{c}$ \\
\hline $\mathrm{SiO}_{2}$ & 48.65 & 50.74 & 52.75 & 48.80 & 52.08 & 52.32 & 52.08 & 52.96 & 53.36 & 49.12 & 52.96 & 52.06 & 51.03 \\
\hline $\mathrm{TiO}_{2}$ & 0.56 & 0.44 & 0.18 & 0.90 & 0.17 & 0.34 & 0.16 & 0.23 & 0.15 & 0.00 & 0.23 & 0.00 & 0.00 \\
\hline $\mathrm{Al}_{2} \mathrm{O}_{3}$ & 5.48 & 3.37 & 1.25 & 4.88 & 0.47 & 2.30 & 1.01 & 1.11 & 1.06 & 0.26 & 1.11 & 0.97 & 0.35 \\
\hline $\mathrm{Cr}_{2} \mathrm{O}_{3}$ & 0.02 & 0.00 & 0.00 & 0.07 & 0.02 & 0.03 & 0.00 & 0.01 & 0.00 & 0.00 & 0.01 & 0.00 & 0.00 \\
\hline $\mathrm{FeO}$ & 10.74 & 9.58 & 21.07 & 10.13 & 26.02 & 11.39 & 18.87 & 20.86 & 20.21 & 34.62 & 20.86 & 14.22 & 28.27 \\
\hline $\mathrm{MnO}$ & 0.26 & 0.28 & 0.70 & 0.34 & 1.54 & 0.38 & 1.26 & 0.73 & 0.64 & 1.75 & 0.73 & 0.86 & 1.51 \\
\hline $\mathrm{MgO}$ & 13.43 & 13.89 & 21.49 & 13.31 & 17.68 & 13.94 & 10.34 & 21.05 & 22.13 & 12.65 & 21.05 & 12.48 & 17.49 \\
\hline $\mathrm{CaO}$ & 18.91 & 20.34 & 1.77 & 19.25 & 1.47 & 18.51 & 16.13 & 1.93 & 1.75 & 1.59 & 1.93 & 19.26 & 1.47 \\
\hline $\mathrm{Na}_{2} \mathrm{O}$ & 0.07 & 0.08 & 0.00 & 0.07 & 0.00 & 0.10 & 0.02 & 0.00 & 0.00 & 0.00 & 0.00 & 0.04 & 0.00 \\
\hline $\mathrm{K}_{2} \mathrm{O}$ & 0.00 & 0.01 & 0.00 & 0.01 & 0.01 & 0.01 & 0.02 & 0.01 & 0.00 & 0.00 & 0.01 & 0.00 & 0.00 \\
\hline Sum & 98.12 & 98.73 & 99.21 & 97.76 & 99.46 & 99.32 & 99.87 & 98.89 & 99.30 & 99.99 & 98.89 & 99.89 & 100.12 \\
\hline $\mathrm{Mg \#}$ & 0.691 & 0.721 & 0.645 & 0.701 & 0.548 & 0.686 & 0.494 & 0.641 & 0.661 & 0.394 & 0.643 & 0.610 & 0.524 \\
\hline Wo & 38.6 & 43.1 & 3.7 & 42.1 & 3.2 & 39.6 & 35.6 & 4.1 & 3.6 & 3.4 & 4.1 & 40.4 & 3.1 \\
\hline En & 43.4 & 41.0 & 62.1 & 40.5 & 53.0 & 41.4 & 31.8 & 61.7 & 63.7 & 38.1 & 61.6 & 36.4 & 50.8 \\
\hline Fs & 18.0 & 15.9 & 34.2 & 17.3 & 43.8 & 19.0 & 32.6 & 34.3 & 32.6 & 58.5 & 34.3 & 23.2 & 46.1 \\
\hline
\end{tabular}


Table 4

Representative plagioclase analyses from Ksudach rocks

\begin{tabular}{|c|c|c|c|c|c|c|c|c|c|c|c|c|c|}
\hline \multirow[t]{2}{*}{ Phase } & \multicolumn{4}{|c|}{ Basaltic andesite } & \multicolumn{3}{|c|}{ Andesite } & \multicolumn{3}{|l|}{ Dacite } & \multicolumn{3}{|c|}{ Rhyodacite } \\
\hline & $\mathrm{mg}, \mathrm{c}$ & $\mathrm{ph}, \mathrm{c}$ & $\mathrm{ph}, \mathrm{c}$ & $\mathrm{m}$ & $\mathrm{ph}, \mathrm{c}$ & $\mathrm{m}$ & $\mathrm{m}$ & $\mathrm{mg}, \mathrm{c}$ & $\mathrm{ph}, \mathrm{c}$ & $\mathrm{ph}, \mathrm{c}$ & $\mathrm{ph}, \mathrm{c}$ & $\mathrm{ph}, \mathrm{c}$ & $\mathrm{m}$ \\
\hline $\mathrm{SiO}_{2}$ & 44.26 & 48.36 & 54.08 & 50.10 & 55.98 & 50.43 & 54.13 & 44.61 & 48.75 & 53.88 & 57.40 & 57.18 & 55.53 \\
\hline $\mathrm{TiO}_{2}$ & 0.00 & 0.00 & 0.00 & 0.00 & 0.00 & 0.01 & 0.04 & 0.00 & 0.00 & 0.00 & 0.00 & 0.00 & 0.00 \\
\hline $\mathrm{Al}_{2} \mathrm{O}_{3}$ & 35.64 & 32.29 & 29.20 & 31.13 & 27.16 & 31.26 & 29.13 & 35.53 & 32.65 & 28.93 & 27.80 & 27.53 & 27.48 \\
\hline $\mathrm{FeO}$ & 0.46 & 0.76 & 0.46 & 0.65 & 0.43 & 0.81 & 0.88 & 0.56 & 0.81 & 0.75 & 0.36 & 0.43 & 0.48 \\
\hline $\mathrm{MnO}$ & 0.02 & 0.02 & 0.02 & 0.00 & 0.00 & 0.00 & 0.00 & 0.00 & 0.00 & 0.02 & 0.00 & 0.02 & 0.00 \\
\hline $\mathrm{MgO}$ & 0.08 & 0.05 & 0.04 & 0.05 & 0.02 & 0.05 & 0.07 & 0.04 & 0.04 & 0.06 & 0.01 & 0.01 & 0.02 \\
\hline $\mathrm{CaO}$ & 19.90 & 15.49 & 11.28 & 13.83 & 9.25 & 13.56 & 11.71 & 19.09 & 14.97 & 11.47 & 9.21 & 9.21 & 9.27 \\
\hline $\mathrm{Na}_{2} \mathrm{O}$ & 0.40 & 2.23 & 4.78 & 3.32 & 5.59 & 3.34 & 4.48 & 0.46 & 2.35 & 4.44 & 6.05 & 6.28 & 6.15 \\
\hline $\mathrm{K}_{2} \mathrm{O}$ & 0.00 & 0.03 & 0.06 & 0.04 & 0.08 & 0.04 & 0.07 & 0.00 & 0.03 & 0.11 & 0.10 & 0.12 & 0.08 \\
\hline Sum & 99.76 & 99.23 & 99.20 & 99.12 & 98.51 & 99.50 & 100.52 & 100.29 & 99.6 & 99.67 & 100.93 & 100.78 & 99.01 \\
\hline Or & 0.00 & 0.2 & 0.3 & 0.2 & 0.5 & 0.2 & 0.4 & 0.0 & 0.2 & 0.7 & 0.6 & 0.7 & 0.5 \\
\hline $\mathrm{Ab}$ & 3.7 & 20.6 & 43.3 & 30.3 & 52.0 & 30.8 & 40.8 & 4.2 & 22.1 & 40.9 & 54.0 & 54.8 & 54.3 \\
\hline An & 96.3 & 79.2 & 56.4 & 69.5 & 47.5 & 69.0 & 58.8 & 95.8 & 77.7 & 58.4 & 45.4 & 44.5 & 45.2 \\
\hline
\end{tabular}

prises ortho- and clinopyroxenes, plagioclase and opaque oxides, with rare olivine. Hornblende is lacking. This pyroxene phenocryst association is typical of the volcanoes of the frontal zone of an island arc, located closer to the subduction zone, while the hornblende-bearing rocks are characteristic of the rear zone volcanoes (Volynets et al., 1990a; Volynets, 1994).

The samples of the main rock types (basaltic andesite, andesite, dacite and rhyodacite) were analyzed by microprobe (Table 1 , analyses 14, 5, 15, and 6 , respectively). Representative minerals analyses are given in Tables 2-5.

The geochemical characteristics of Ksudach rocks are typical for low-K island arc series (Volynets et al., 1990b). They have low concentration of $\mathrm{Rb}, \mathrm{Ba}$, $\mathrm{La}$, Th (Table 6) and uniformly low $\mathrm{La} / \mathrm{Yb}(1.5-$ 2.0), $\mathrm{Zr} / \mathrm{Y}(3.1-3.4)$, and $\mathrm{Th} / \mathrm{Yb}(0.19-0.24)$ ratios (Fig. 8). The ${ }^{87} \mathrm{Sr} /{ }^{86} \mathrm{Sr}$ ratios (Table 7) are identical in all-Ksudach rocks and similar to the olivineclinopyroxene-plagioclase inclusions (Bailey et al., 1987). All these data suggest that the Ksudach magmas originated as a result of fractionation of a primary parental melt. A direct indication of this process is provided by the groundmass compositions of the rocks. The average composition of the basaltic andesite groundmass (recalculated volatile-free) is similar in composition to typical Ksudach andesite. Also the groundmass of the andesites is similar in composition to typical dacite (Table 5). Calculations

Table 5

Representative groundmass (gm) and glass (gl) analyses from Ksudach rocks

\begin{tabular}{|c|c|c|c|c|c|c|c|c|c|c|c|c|}
\hline \multirow[t]{2}{*}{ Phase } & \multicolumn{3}{|c|}{ Basaltic andesite } & \multicolumn{4}{|c|}{ Andesite } & \multicolumn{4}{|c|}{ Dacite } & \multirow{2}{*}{$\begin{array}{l}\text { Rhyodacite } \\
\text { gl }\end{array}$} \\
\hline & gm & $\mathrm{gm}$ & gm & gm & $\mathrm{gl}$ & $\mathrm{gl}$ & gl & gl & $\mathrm{gl}$ & gl & gl & \\
\hline $\mathrm{SiO}_{2}$ & 60.98 & 61.43 & 62.04 & 63.74 & 61.99 & 63.87 & 70.95 & 59.63 & 59.75 & 68.79 & 70.05 & 70.05 \\
\hline $\mathrm{TiO}_{2}$ & 0.82 & 0.83 & 0.82 & 1.47 & 0.84 & 0.68 & 0.35 & 0.79 & 0.96 & 0.61 & 0.48 & 0.13 \\
\hline $\mathrm{Al}_{2} \mathrm{O}_{3}$ & 15.40 & 15.00 & 15.37 & 15.68 & 16.62 & 16.38 & 14.85 & 15.23 & 13.60 & 13.61 & 14.89 & 14.73 \\
\hline $\mathrm{FeO}$ & 8.26 & 8.60 & 8.14 & 6.20 & 7.06 & 6.62 & 3.51 & 8.96 & 10.76 & 5.88 & 5.01 & 3.98 \\
\hline $\mathrm{MnO}$ & 0.29 & 0.27 & 0.22 & 0.18 & 0.17 & 0.18 & 0.13 & 0.24 & 0.34 & 0.24 & 0.17 & 0.17 \\
\hline $\mathrm{MgO}$ & 2.06 & 2.33 & 1.66 & 1.92 & 2.52 & 1.89 & 0.52 & 1.90 & 2.98 & 1.07 & 0.79 & 0.48 \\
\hline $\mathrm{CaO}$ & 5.56 & 5.27 & 5.15 & 4.93 & 5.73 & 5.07 & 2.76 & 6.52 & 5.95 & 3.94 & 3.58 & 2.41 \\
\hline $\mathrm{Na}_{2} \mathrm{O}$ & 3.98 & 4.05 & 4.31 & 4.06 & 3.21 & 3.72 & 4.08 & 2.72 & 3.21 & 3.43 & 3.79 & 3.83 \\
\hline $\mathrm{K}_{2} \mathrm{O}$ & 0.76 & 0.81 & 0.91 & 0.96 & 0.82 & 0.90 & 1.32 & 0.51 & 0.90 & 0.99 & 1.20 & 1.36 \\
\hline Sum & 98.62 & 98.60 & 98.63 & 99.13 & 98.95 & 99.31 & 98.46 & 96.50 & 98.46 & 98.58 & 99.96 & 97.13 \\
\hline $\mathrm{FeO} / \mathrm{MgO}$ (wt.\%) & 4.00 & 3.72 & 4.90 & 3.23 & 2.80 & 3.50 & 8.29 & 4.71 & 3.68 & 5.49 & 6.34 & 6.75 \\
\hline
\end{tabular}


Table 6

Selected major and trace elements analyses of Ksudach rocks

\begin{tabular}{|c|c|c|c|c|c|c|c|}
\hline Number & 1 & 2 & 3 & 4 & 5 & 6 & 7 \\
\hline Samples & 7448 & 7452 & $8811 / 1$ & $86038 / 7$ & $8880 / 5$ & $8802 / 2$ & $8825 / 9$ \\
\hline $\mathrm{SiO}_{2}$ & 51.87 & 53.48 & 62.57 & 70.39 & 71.78 & 70.09 & 67.8 \\
\hline $\mathrm{K}_{2} \mathrm{O}$ & 0.43 & 0.44 & 1.15 & 1.43 & 1.57 & 1.45 & 1.34 \\
\hline $\mathrm{Rb}$ & 4 & 7 & 13 & 21 & 22 & 22 & 19 \\
\hline Cs & 0.11 & - & 1.28 & 1.66 & 1.71 & - & - \\
\hline $\mathrm{La}$ & 3.45 & - & 7.15 & 8.41 & 8.91 & 6 & 7 \\
\hline $\mathrm{Ce}$ & 9.7 & - & 21.2 & 21.9 & 24.0 & 19 & 22 \\
\hline $\mathrm{Nd}$ & - & - & - & 15.8 & 19.4 & 18 & 18 \\
\hline $\mathrm{Sm}$ & 2.44 & - & 5.04 & 5.33 & 5.76 & - & - \\
\hline $\mathrm{Eu}$ & 0.88 & - & 1.29 & 1.30 & 1.27 & - & - \\
\hline $\mathrm{U}$ & - & - & 0.30 & 0.34 & 0.57 & - & - \\
\hline $\mathrm{Zr}$ & - & 58 & - & - & - & 162 & 142 \\
\hline Hf & 1.45 & - & 4.14 & 4.61 & 4.88 & - & - \\
\hline $\mathrm{Nb}$ & - & 1.2 & - & - & - & 2.4 & 2.4 \\
\hline $\mathrm{Ta}$ & - & - & 0.11 & 0.13 & 0.13 & - & - \\
\hline Y & - & 23 & - & - & - & 52 & 47 \\
\hline $\mathrm{Sc}$ & 37 & 36 & 21.1 & 15.4 & 14.1 & 13 & 17 \\
\hline $\mathrm{Co}$ & 28 & 25 & 9.4 & 3.8 & 2.9 & 4 & 8 \\
\hline $\mathrm{Ni}$ & - & 10 & - & - & - & 2 & 4 \\
\hline $\mathrm{Cr}$ & 63 & 26 & 5 & 5 & 2 & 4 & 7 \\
\hline
\end{tabular}

1-Late Pleistocene lava flow; 2-bomb, Shtyubel' Cone; $3-7$-pumice bombs and lapilli $\left(3-\mathrm{KS}_{2}, 4-7-\mathrm{KS}_{1}\right)$. Analyses $1,3-5$ were made in New Mexico Institute of Mining and Technology, USA by Dr. Ph. Kyle using INAA method. Analyses 2, 6 and 7 were made in Kopenhagen University, Denmark by Dr. J. Bailey using XRF method. $\mathrm{SiO}_{2}, \mathrm{Na}_{2} \mathrm{O}$ and $\mathrm{K}_{2} \mathrm{O}$ in wt.\%, other elements-in ppm. Dash means that the concentration of the element has not been determined.

based on rare-earth elements contents in Ksudach rocks and coefficients of their distribution in minerals of olivine-clinopyroxene-plagioclase xenoliths showed that this initial melt might have basaltic composition and the remainder dacite-rhyodacite fraction may reach 25\%-30\%. (Volynets et al., 1990b). The above-mentioned xenoliths are considered to be cumulates formed due to proto-crystallization of basaltic melt and thus are complementary to silicic melts (Volynets et al., 1978; Selyangin, 1990).

The most silicic melts are erupted during the initial stages of a caldera-forming eruption. The amount of silicic material accumulated in a chamber before each eruption is likely to depend on the duration of the preceding repose period (Figs. 5 and 6 ). The largest volume of rhyodacite was erupted during the $\mathrm{KS}_{1}$ eruption and may be explained by the long repose period (more than 5000 years) interrupted only by KSbt and a few more eruptions of minor volume.

The earlier-described heterogeneity of most Ksudach tephras (i.e., coexistence of silicic and relatively mafic pumice in the same units and abundance of taxitic pumice varieties with alternating silicic and mafic bands) suggests intensive mixing of the fractionated melt in the course of Ksudach eruptions. Disequilibrium phenocryst associations in most of the rocks, and the presence of glass of variable composition in the groundmass of silicic rocks (Tables 2-5) support this suggestion and allow us to presume that this mixing took place immediately prior to the eruptions. 


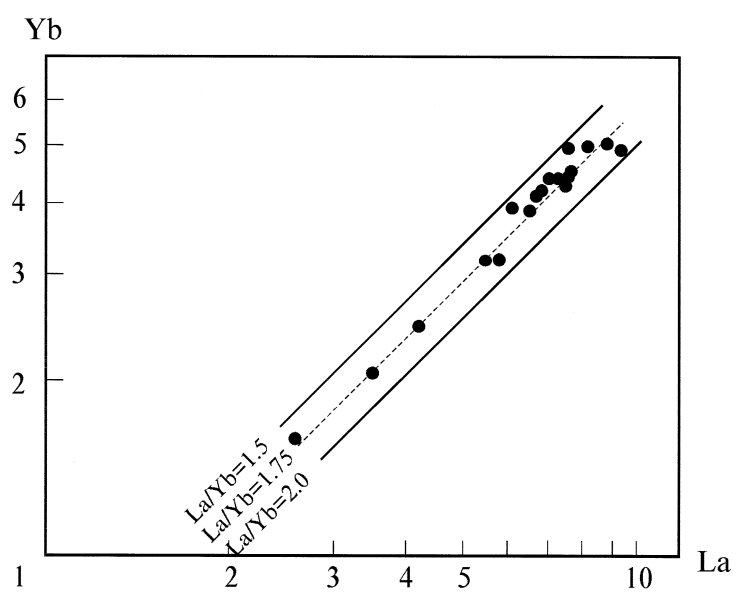

Fig. 8. $\mathrm{La}-\mathrm{Yb}$ ratio variations in the Ksudach volcanic rocks. Data from Table 6 supplemented by previously published data after Volynets et al. (1990b).

The dacitic pumice of the KSht ${ }_{1}$ eruption (Table 1 , analysis 15) offers one of the best examples of this mixing process. This is olivine-two pyroxeneplagioclase rock with a glassy groundmass. The range of composition of the plagioclase phenocrysts $\left(\mathrm{An}_{58-96}\right)$ exactly coincides with that in basaltic andesitic scoria of the lower subunit of the same eruption (Table 1, analysis 14; Table 4). Along with phenocrysts of Fe-rich and low-alumina clinopyroxene $\left(\mathrm{Mg} \#=0.49-0.54, \mathrm{Al}_{2} \mathrm{O}_{3}=0.9-1.0 \mathrm{wt} . \%\right)$ and orthopyroxene $\left(\mathrm{Mg} \#=0.39-0.45, \mathrm{Al}_{2} \mathrm{O}_{3}=0.25\right.$ 0.45 wt.\%) phenocrysts of higher $\mathrm{Mg}$ and $\mathrm{Al}$ clinoand orthopyroxene $(\mathrm{Mg} \#=0.69-0.75$ and 0.64 $0.68, \mathrm{Al}_{2} \mathrm{O}_{3}=1.8-3.8$ and $0.8-1.1$ wt. $\%$, respectively), very similar to those from basaltic andesitic scoria, are common (Table 3). The first of them contain inclusions of ferrous $(\mathrm{Mg} \#=0.03-0.04)$ titanomagnetite with high (about $17 \%$ ) $\mathrm{TiO}_{2}$ content and ferrous $(\mathrm{Mg} \#=0.07)$ ilmenite, the latter-inclusions of less ferrous $(\mathrm{Mg} \#=0.12-0.17)$ and titanium $\left(\mathrm{TiO}_{2}=5-9\right.$ wt.\%) titanomagnetite (Table 2) similar to that from inclusions in pyroxenes from basaltic andesite $\left(\mathrm{Mg} \#=0.12-0.17 ; \mathrm{TiO}_{2}=5.5-9.3\right.$ wt.\%). Olivine phenocrysts $\left(\mathrm{Fo}_{70-73}\right)$ from the dacite under consideration are similar to these from andesite. Glass from the groundmass of this dacite corresponds dominantly to rhyodacite but sometimes to andesite as well (Table 5). Pyroxenes from dacite have lower $\mathrm{Mg} \#$ and $\mathrm{Al}_{2} \mathrm{O}_{3}$ contents than homogeneous pyroxenes from rhyodacite: clinopyroxenes$\mathrm{Mg} \#=0.58-0.62, \mathrm{Al}_{2} \mathrm{O}_{3}=0.9-2.0 \mathrm{wt} . \%$; orthopyroxenes- $\mathrm{Mg} \#=0.52-0.55, \quad \mathrm{Al}_{2} \mathrm{O}_{3}=0.3-0.7$ wt.\%) (Fig. 9, Table 3). These data suggest that the silicic melt that mixed with mafic melt to form the

Table 7

Isotope data for the tephra erupted during the current cycle of Ksudach activity and $\mathrm{KS}_{2}$ eruption

\begin{tabular}{|c|c|c|c|c|c|c|c|c|c|}
\hline Samples & Codes of the eruptions & $\begin{array}{l}\text { Calendar } \\
\text { ages }\end{array}$ & $\begin{array}{l}\mathrm{SiO}_{2} \\
\text { (wt.\%) }\end{array}$ & $\begin{array}{l}\mathrm{FeO}^{*} / \\
\mathrm{MgO}\end{array}$ & $\begin{array}{l}{ }^{87} \mathrm{Sr} / \\
{ }^{86} \mathrm{Sr}^{1}\end{array}$ & $\begin{array}{l}\text { Error } \\
(2 \sigma)\end{array}$ & $\begin{array}{l}{ }^{143} \mathrm{Nd} / \\
{ }^{144} \mathrm{Nd}^{2}\end{array}$ & $\begin{array}{l}\text { Error } \\
(2 \sigma)\end{array}$ & $\varepsilon \mathrm{Nd}$ \\
\hline $8880 / 1$ & $\mathrm{KSht}_{3}$, upper subunit & AD 1907 & 60.85 & 2.94 & 0.703311 & 13 & 0.513128 & 12 & 9.46 \\
\hline $8880 / 1 \mathrm{a}$ & $\mathrm{KSht}_{3}$, upper subunit & AD 1907 & 56.91 & 2.52 & 0.703309 & 20 & 0.513101 & 16 & 8.93 \\
\hline $86038 / 6$ & $\mathrm{KSht}_{3}$, lower subunit & AD 1907 & 56.58 & 1.72 & 0.703276 & 14 & 0.513104 & 13 & 8.99 \\
\hline $8883 / 6$ & $\mathrm{KSht}_{2}$, upper subunit & $\approx 1650$ & 62.08 & 3.25 & 0.703304 & 13 & 0.513117 & 11 & 9.25 \\
\hline $8885 / 6$ & - & $?$ & 55.25 & 2.44 & 0.703315 & 13 & 0.513102 & 19 & 8.95 \\
\hline $8885 / 5$ & - & $?$ & 57.68 & 2.95 & 0.703324 & 14 & 0.513115 & 13 & 9.21 \\
\hline $8960 / 1$ & $\mathrm{KSht}_{1}$, upper subunit & $\approx 1000$ & 64.09 & 3.00 & 0.703303 & 15 & 0.513105 & 13 & 9.01 \\
\hline $8960 / 2$ & $\mathrm{KSht}_{1}$, lower subunit & $\approx 1000$ & 56.74 & 2.42 & 0.703295 & 16 & 0.513108 & 15 & 9.07 \\
\hline $8885 / 3$ & - & $?$ & 58.92 & 2.83 & 0.703336 & 14 & 0.513101 & 19 & 8.93 \\
\hline $88150 / 1$ & - & $\approx 350$ & 60.05 & 3.08 & 0.703298 & 16 & 0.513096 & 12 & 8.84 \\
\hline $8880 / 5 a$ & $\mathrm{KS}_{1}$, upper gray subunit & $\approx 240$ & 70.95 & 3.21 & 0.703389 & 15 & 0.513130 & 12 & 9.50 \\
\hline $8880 / 5$ & $\mathrm{KS}_{1}$, lower white subunit & $\approx 240$ & 71.78 & 3.52 & 0.703370 & 13 & 0.513083 & 14 & 8.58 \\
\hline $8811 / 1$ & $\mathrm{KS}_{2}$ & BC 4700 & 62.57 & 3.03 & 0.703312 & 15 & 0.513097 & 17 & 8.86 \\
\hline
\end{tabular}

The samples of the erupted products of cycle IV are enlisted in the consecutive order beginning from the most recent KSht ${ }_{3}$ (1907) eruption. $\mathrm{FeO}^{*}=0.9 \mathrm{Fe}_{2} \mathrm{O}_{3}+\mathrm{FeO}$.

${ }^{1}$ Normalized to ${ }^{86} \mathrm{Sr} /{ }^{88} \mathrm{Sr}=0.1194$; reproducibility $(2 \sigma)= \pm 0.00002$; NBS987 ${ }^{87} \mathrm{Sr} /{ }^{86} \mathrm{Sr}=0.710226$.

${ }^{2}$ Normalized to ${ }^{146} \mathrm{Nd} /{ }^{144} \mathrm{Nd}=0.7219 ; \varepsilon \mathrm{Nd}=\left[\left({ }^{143} \mathrm{Nd} /{ }^{144} \mathrm{Nd}\right) / 0.51264-1\right] \times 10^{4}$; reproducibility $(2 \sigma)= \pm 0.3 \varepsilon \mathrm{Nd}$; UCSD ${ }^{143} \mathrm{Nd} /$ ${ }^{144} \mathrm{Nd}=0.511845$. 


\section{Clinopyroxenes}
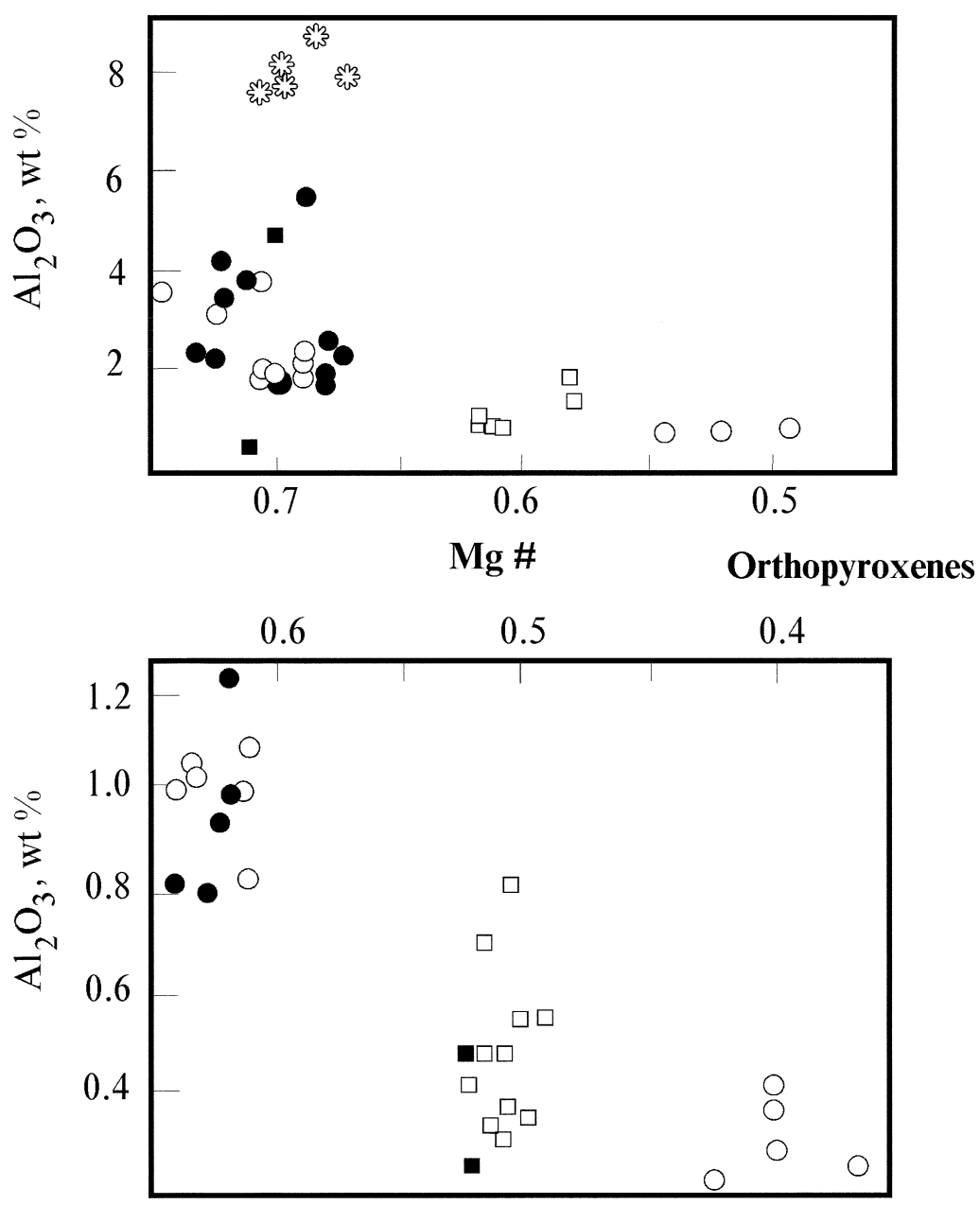

Composition of pyroxenes from the Ksudach rocks:

\& olivine-clinopyroxeneanorthite inclusions

- basaltic andesite
- andesite

$\bigcirc$ dacite

$\square$ rhyodacite

Fig. 9. Composition of pyroxenes from the Holocene Ksudach rocks. $\mathrm{Mg} \#=\mathrm{Mg} /(\mathrm{Mg}+\mathrm{Fe})$ (in mol).

$\mathrm{KSht}_{1}$ dacitic pumice was more evolved than rhyodacite and probably corresponded to rhyolite. The mafic component might have been basaltic andesite, as suggested by bulk composition of the most mafic 
erupted products and magnesian phenocryst association in dacite. Evidence of magma mixing is present in all other examined samples as well. For example, andesite contains calcium-rich plagioclase $\left(\mathrm{An}_{58-69}\right)$ along with andesine $\left(\mathrm{An}_{43-49}\right)$ which is typical for rhyodacite (Table 4) and the glasses of andesitic to rhyodacitic composition (Table 5).

\section{Temperatures of crystallization}

Minerals analyses (Tables 2-5) allow us to estimate PT-parameters of the melts prior to their eruption. Using the magnetite-ilmenite geothermometer-geobarometer (Ghiorso and Sack, 1991), the temperature of crystallization of titanomagnetite and ilmenite inclusions in pyroxene phenocrysts from rhyodacite range from 892 to $915^{\circ} \mathrm{C}$ and $\log f_{\mathrm{O}_{2}}$ of 11.5-12.1 which is close to the NNO buffer. Similar temperatures are calculated using the two pyroxene geothermometer (Wood and Banno, 1973) for crystallization of pyroxenes from rhyodacite $\left(896-907^{\circ} \mathrm{C}\right)$ as well as for ferrous pyroxenes from dacite (881$910^{\circ} \mathrm{C}$ ). The good agreement among these results suggests their reliability. Crystallization temperatures calculated for more magnesian pyroxenes from the same dacite are essentially higher $\left(923-1007^{\circ} \mathrm{C}\right)$ and are close to those obtained for pyroxenes from basaltic andesite of the same eruption $\left(967-986^{\circ} \mathrm{C}\right)$. The modeling of Thomas and Sparks (1992) suggests that welding of fall deposits to distances of about 1 $\mathrm{km}$ is compatible with magmatic temperatures of $\approx 1000^{\circ} \mathrm{C}$. So we can assume such temperatures for $\mathrm{KS}_{4}$ and $\mathrm{KS}_{2}$ andesitic and $\mathrm{KSht}_{1}$ andesitic-dacitic tephras which are welded near the source. The high temperature of the basaltic andesite magma which might have intruded into a shallow silicic chamber from some deeper source (as suggested by petrographic and mineralogical evidence) might have caused overheating of the silicic melt and thus triggered catastrophic eruptions.

\section{5. $\mathrm{H}_{2} \mathrm{O}$ content}

The presence of two pyroxene-plagioclase aggregates allows to assume close crystallization temperatures for all the minerals of such aggregates. Since the temperatures for pyroxenes have already been calculated we used the geothermometer of Kudo and Weill (1970) to estimate $P_{\mathrm{H}_{2} \mathrm{O}}$ under which the crystallization of this mineral association took place. It appears that $P_{\mathrm{H}_{2} \mathrm{O}}$ both for rhyodacitic and basaltic andesitic melts had the same range of 1.5-2.0 kbar. According to experimental data (Kadik et al., 1971) such $P_{\mathrm{H}_{2} \mathrm{O}}$ values correspond to $4.5-5.5 \mathrm{wt} \%$ of water in silicic melts at a temperature of about $900^{\circ} \mathrm{C}$ and to approximately 3.0-3.8 wt.\% of water in mafic melts at about $1000^{\circ} \mathrm{C}$. Additional evidence of high volatile contents includes their high explosivity that is obvious in view of predominance of the pyroclastic material among the products of silicic volcanism.

\section{Isotopic composition}

In order to trace the extent and possible changes in the degree of contamination of the erupted products we determined the $\mathrm{Sr}$ and $\mathrm{Nd}$ isotope ratios in products of consecutive eruptions of the current active period, beginning from the $\mathrm{KS}_{1}$ caldera-forming eruption through the Shtyubel' Cone eruptions (Table 7, Figs. 5 and 10). Values were also measured in the $\mathrm{KS}_{2}$ andesitic pumice.

Variations of $\mathrm{Nd}$ and $\mathrm{Sr}$ isotope ratios in the Ksudach rocks are small: ${ }^{143} \mathrm{Nd} /{ }^{144} \mathrm{Nd}=0.513083$ $0.513130(\varepsilon \mathrm{Nd} 8.6-9.5),{ }^{87} \mathrm{Sr} /{ }^{86} \mathrm{Sr}=0.703276-$ 0.703389 (Table 7). Sr isotope ratios reported here are close to those reported for Ksudach rocks by Vinogradov et al. (1986) - 0.70325-0.70334, but are somewhat lower than those reported by Bailey et al. (1987) for lavas and holocrystalline related inclusions (0.70334-0.70347).

The low variability in $\mathrm{Nd}$ and $\mathrm{Sr}$ isotopes and lack of correlation with silica content suggest the absence of significant contamination of melts by crustal material. Variations in $\mathrm{Sr}$ and $\mathrm{Nd}$ isotope ratios in Ksudach rocks are similar to those from most other Kamchatkan lavas. Of 162 analyses of ${ }^{87} \mathrm{Sr} /{ }^{86} \mathrm{Sr}$ more than $80 \%$ fall within the $0.7031-0.7036$ range, and of 44 determinations of $\varepsilon \mathrm{Nd}, 86 \%$ fall within 8.3-9.6 (based on the analysis of unpublished data by Volynets and data by Vinogradov et al. (1986) and Bailey et al. (1987)). Altogether, these data support negligible amounts of contamination of Ksudach magmas. 


\section{Ksudach eruptions}
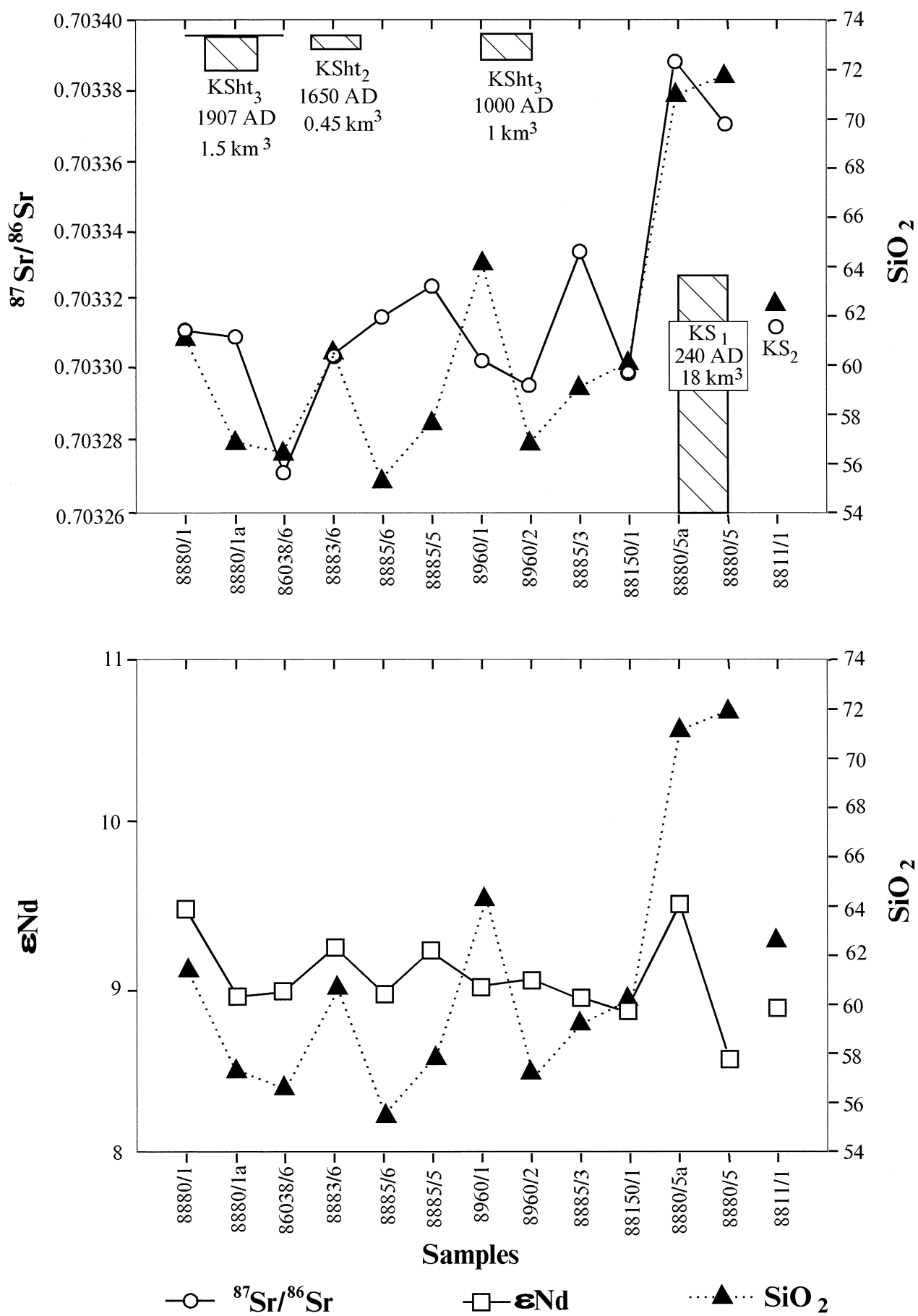

Fig. 10. $\mathrm{Sr}$ and $\mathrm{Nd}$ isotopic ratio and $\mathrm{SiO}_{2}$ variations with time of the Ksudach products erupted during the last 1800 years. The samples on the $x$-axis are arranged from left to right, from young to old. $\mathrm{KS}_{2}$ and $\mathrm{KS}_{1}$ present the last two caldera eruptions in this area. KSht ${ }_{1}$, $\mathrm{KSht}_{2}$ and $\mathrm{KSht}_{3}$ are the three larger post-caldera eruptions of Shtyubel' Cone. The volumes of the eruptions are from Braitseva et al. (1996). 
Nevertheless, the $\mathrm{KS}_{1}$ rhyodacite pumices, which are the most silicic and the most voluminous of all the Ksudach erupted products, show the highest $\mathrm{Sr}$ isotopic ratios (Table 7, Fig. 10). The ${ }^{87} \mathrm{Sr} /{ }^{86} \mathrm{Sr}$ values for the rocks of this and following Shtyubel' Cone eruptions suggest the possibility of minor crustal contamination.

A general increase of $\varepsilon \mathrm{Nd}$ values and decrease in ${ }^{87} \mathrm{Sr} /{ }^{86} \mathrm{Sr}$ values in consecutively erupted during the current period of activity since AD 240 to 1907 products is seen in Fig. 10. This suggests that during the last $\approx 1700$ years, more depleted (less contaminated) melts are coming to the surface. The most contaminated melts correspond to rhyodacitic pumice of the $\mathrm{KS}_{1}$ caldera-forming eruption $(\varepsilon \mathrm{Nd}=8.58$; $\left.{ }^{87} \mathrm{Sr} /{ }^{86} \mathrm{Sr}=0.703370\right)$, and to andesitic tephra of the initial eruption of Shtyubel' Cone $(\varepsilon \mathrm{Nd}=8.84$; $\left.{ }^{87} \mathrm{Sr} /{ }^{86} \mathrm{Sr}=0.703298\right)$. This suggests that a more contaminated silicic chamber was emptied in the course of the $\mathrm{KS}_{1}$ eruption and the initial eruptions of Shtyubel' Cone. Silicic subunits of the $\mathrm{KSht}_{1}$ and $\mathrm{KSht}_{3}$ eruptions have isotopic characteristics similar to those of corresponding mafic subunits (Table 7, Figs. 5 and 10). This likely indicates that these silicic melts were derived from the new portions of mafic magmas and are not the remaining portion of the $\mathrm{KS}_{1}$ melt.

\section{Discussion}

Mineralogical, geochemical and isotopic data support the conclusion that all the rocks erupted by the Ksudach volcano during Holocene, originated as a result of fractionation of some initial mafic melt, while the role of other processes (e.g., contamination, assimilation) was insignificant. All the eruption products exhibit evidence of mixing of the fractionated melt prior to and during the course of the eruptions. Therefore, the eruptions producing ejecta of varying composition might have been triggered by injections of some new portions of mafic melt into the silicic chamber. These injections caused intensive mixing of the melts, and overheating and boiling of the silicic melts which resulted in the onset of an eruption. The olivine-clinopyroxene-plagioclase inclusions, abundant in the products of the $\mathrm{KS}_{2}$ and
Shtyubel' Cone larger eruptions, might indicate that, during these eruptions, a fractionated magma chamber was nearly emptied.

The larger eruptions of Shtyubel' Cone are of particular interest as they produced both mafic and evolved silicic material. The latter likely represents newly fractionated silicic melt rather than the remainder of the pre- $\mathrm{KS}_{1}$, as suggested by the close $\varepsilon \mathrm{Nd}$ values in mafic and silicic products of the same eruptions, which both are higher than in the $\mathrm{KS}_{1}$ material. This suggests that the conditions favouring the storage of mafic melt and its fractionation still exist under Ksudach volcano. Geophysical data also indicate a large positive gravity anomaly associated with Ksudach calderas, which has been interpreted as a cylindrical magma body with an upper border 3.5 $\mathrm{km}$ deep (Selyangin, 1991). Dormant periods as long as only few hundreds of years likely are sufficient for fractionation of about $0.2-0.8 \mathrm{~km}^{3}$ of silicic melt in this magma chamber (Fig. 6).

The eruptive history of Ksudach demonstrates a change of regime from separate large eruptions to frequent smaller eruptions. It might be interpreted as discrete pulses of mafic melts supply during the first part of the Holocene time and more frequent ones during the current cycle. These pulses might have been caused by some processes in the mantle magma generation zone which change tensions in the crust and allow new portions of magma to penetrate into its uppermost horizons. It is noteworthy that the largest $\mathrm{KS}_{1}$ eruption as well the birth of Shtyubel' Cone fall into the period of general all-Kamchatka upsurge of volcanic activity $\left(1800-1300{ }^{14} \mathrm{C}\right.$ years $\mathrm{BP})$ when many other powerful eruptions were documented (Braitseva et al., 1995). At the same time, the period of the intensive Ksudach activity beginning with these eruptions (current cycle), coincides with long dormant periods of the neighbouring volcanoes Khodutka, Zheltovsky, Iliinsky, and Dikii Greben' (Fig. 1; Melekestsev et al., 1990; Ponomareva et al., submitted).

${ }^{87} \mathrm{Sr} /{ }^{86} \mathrm{Sr}$ and $\varepsilon \mathrm{Nd}$ values in the products of more frequent but smaller eruptions of current cycle are closer to depleted mantle values, than those in the rocks of the larger $\mathrm{KS}_{1}$ and $\mathrm{KS}_{2}$ eruptions. This trend in isotopic variations is opposite to that observed in 1991-1995 dome eruption of Unzen volcano, Japan (Chen et al., 1990, 1999). Thus, in the 
Ksudach case, the most contaminated melt corresponding to rhyodacitic pumice of the caldera-forming eruption $\mathrm{KS}_{1}\left(\varepsilon \mathrm{Nd}=8.58,{ }^{87} \mathrm{Sr} /{ }^{86} \mathrm{Sr}=\right.$ $0.703370)$ indicates that the ratio of recharge/assimilation $(\mathrm{R} / \mathrm{A})$ in the magma chamber is relatively lower on RAFC model (recharge-assimilation-fractional crystallization model) (Chen et al., 1990; DePaolo et al., 1992). On the other hand, a general increase of $\varepsilon \mathrm{Nd}$ values and decrease of ${ }^{87} \mathrm{Sr} /{ }^{86} \mathrm{Sr}$ values observed in the products of smaller postcaldera eruptions can be interpreted as reflecting gradual increase of the $\mathrm{R} / \mathrm{A}$ ratio with time. The reason of difference could be derived from the relatively small size of recharged mafic magma injection into the large caldera magma chamber.

Our evaluations of water content in intermediatesilicic Ksudach rocks based on mineralogical data are significant (4.5-5.5 wt.\%), and these estimates are confirmed by the high explosive activity of Ksudach. The calculated water content is high enough for crystallization of hornblende (Kadik et al., 1986). However, the high temperatures of the melts (about $900^{\circ} \mathrm{C}$ ) inhibit its crystallization. Experimental data show the upper temperature limit of hornblende crystallization in andesitic melts is $930^{\circ} \mathrm{C}$ at $P_{\mathrm{H}_{2} \mathrm{O}} 1.5-2$ kbar (Kadik et al., 1986), and $850-880^{\circ} \mathrm{C}$ in dacitic melts (Hitarov et al., 1969). Hence, we suggest that the typical cross-arc transition from pyroxene phenocryst associations of the frontal zone to the hornblende-bearing ones of the rear zone (Volynets et al., 1990a) might be interpreted as resulting from the higher temperatures of crystallization of the melts from the frontal zone rather than by increasing water content.

\section{Acknowledgements}

The research described in this paper was supported by Grant No. 97-05-64055 from the Russian Basic Research Foundation and by National Science and Technology Program 'Global Environmental and Climatic Change'. The isotopic research was funded by the National Science Council, ROC under grant NSC87-2116-M-001-002 (CHC). Authors thank Philip Kyle (Institute of Mining and Technology, Socorro, USA) and John Bailey (Kopenhagen Uni- versity, Denmark) for trace elements analyses, and Natalia Zaretskaia (Geological Institute, Moscow, Russia) for radiocarbon ages determinations. Philip Kyle's reviewing of the first version of the manuscript is greatly appreciated. The authors are grateful to James Brophy and an anonymous for thorough reviewing the manuscript and valuable comments.

\section{References}

Bailey, J., Larsson, O., Frolova, T.I., 1987. Strontium isotope variations in Lower Tertiary-Quaternary volcanic rocks from the Kurile island arc. Contrib. Mineral. Petrol. 95, 155-165.

Braitseva, O.A., Melekestsev, I.V., Ponomareva, V.V., Kirianov, V.Yu., Litasova, S.N., Sulerzhitsky, L.D., 1992. Tephra of the largest pre-historic eruptions of Kamchatkan volcanoes in Holocene. Quarternary Int. 13 (14), 177-180.

Braitseva, O.A., Melekestsev, I.V., Ponomareva, V.V., Sulerzhitsky, L.D., 1995. The ages of calderas, large explosive craters and active volcanoes in the Kuril-Kamchatka region, Russia. Bull. Volcanol. 57 (6), 383-402.

Braitseva, O.A., Melekestsev, I.V., Ponomareva, V.V., Kirianov, V.Yu., 1996. The caldera-forming eruption of Ksudach volcano about cal. AD 240, the greatest explosive event of our era in Kamchatka. J. Volcanol. Geotherm. Res. 70 (1-2), 49-66.

Braitseva, O.A., Sulerzhitsky, L.D., Ponomareva, V.V., Melekestsev, I.V., 1997a. Geochronology of the greatest Holocene explosive eruptions in Kamchatka and their imprint on the Greenland glacier shield. Transactions (Doklady) of the Russian Academy of Sciences: Earth Science Section 352 (1), $138-140$

Braitseva, O.A., Ponomareva, V.V., Sulerzhitsky, L.D., Melekestsev, I.V., Bailey, J., 1997b. Holocene key-marker tephra layers in Kamchatka, Russia. Quaternary Research 47, 125-139.

Bursik, M.I., Melekestsev, I.V., Braitseva, O.A., 1993. Most recent fall deposits of Ksudach volcano, Kamchatka, Russia. Geophys. Res. Lett. 20 (17), 1815-1818.

Chen, C.H., Lee, T., Shieh, Y.N., Chen, C.H., Mertzman, A., 1990. Nd-Sr-O isotopic evidence for source contamination and unusual mantle component under Luzon arc. Geochim. Cosmochim. Acta 54, 2473-2483.

Chen, C.H., Nakada, S., Shieh, Y.N., DePaolo, D.J., 1999. The $\mathrm{Sr}, \mathrm{Nd}$ and O isotopic studies of the 1991-1995 eruption at Unzen. Japan. J. Volcanol. Geotherm. Res. 89, 243-253.

DePaolo, D.J., Perry, F.V., Baldridge, W.S., 1992. Crustal vs. mantle sources of granitic magmas: a two parameter model based on Nd isotopic studies. Proc. R. Soc. Edinburgh 83, 439-446.

Ghiorso, M.S., Sack, R.O., 1991. Fe-Ti oxide geothermometry: thermodynamic formulation and estimation of intensive variables in silicic magmas. Contrib. Mineral. Petrol. 108 (4), 485-510. 
Gill, J., 1981. Orogenic Andesites and Plate Tectonics. Springer, Berlin, 390 pp.

Hitarov, N.I., Nagapetyan, L.B., Lebedev, E.B., 1969. Crystallization of dacitic melt under the water pressure 500-3000 $\mathrm{kg} / \mathrm{cm}^{2}$. Geochemistry $1,8-14$, in Russian.

Hulten, E., 1924. Eruption of a Kamchatka volcano in 1907 and its atmospheric consequences. Geol. Foren. Forhandl. 46, 407-417.

Kadik, A.A., Lebedev, E.B., Hitarov, N.I., 1971. Water in Magmatic Melts. Nauka, Moscow, 267 pp. (in Russian).

Kadik, A.A., Maksimov, A.P., Ivanov, B.V., 1986. Physical and Chemical Conditions of Crystallization and Genesis of Andesites. Nauka, Moscow, 158 pp. (in Russian).

Kudo, A.W., Weill, D.F., 1970. An igneous plagioclase thermometer. Contrib. Mineral. Petrol. 25 (1), 52-65.

Macias, J.L., Sheridan, M.F., 1995. Products of the 1907 eruption of Shtyubel' Volcano, Ksudach Caldera, Kamchatka, Russia. GSA Bulletin 107 (8), 969-986.

Melekestsev, I.V., Braitseva, O.A., Ponomareva, V.V., Sulerzhitsky, L.D., 1990. Ages and dynamics of the active volcanoes of the Kurile-Kamchatka region. Int. Geol. Rev. 32 (5), 436-448.

Melekestsev, I.V., Braitseva, O.A., Ponomareva, V.V., Sulerzhitsky, L.D., 1996. Holocene catastrophic caldera-forming eruptions of Ksudach volcano, Kamchatka. Volcanol. Seismol. 17, 395-421.

Myashiro, A., 1974. Volcanic rock series in island arcs and active continental margins. Am. J. Sci. 274 (4), 321-355.

Paulick, H., Franz, G., 1997. The color of the pumice: case study on a trachytic fall deposit, Meidob volcanic field, Sudan. Bull. Volcanol. 59, 171-185.

Ponomareva, V.V., Sulerzhitsky, L.D., Dirksen, O.V., Zaretskaia, N.E. (submitted), Holocene paleosols as records of the volcanic rest in the Kurile Lake region, South Kamchatka. Quaternaire.

Selyangin, O.B., 1990. Geologic structure and evolution of the calderas of Ksudach volcano. Volcanol. Seismol. 9 (5), 690713.

Selyangin, O.B., 1991. Ksudach volcano. In: Fedotov, S.A., Masurenkov, Yu.P. (Eds.), Active Volcanoes of Kamchatka.
Nauka, Moscow, pp. 337-353 (in Russian, summary in English).

Stuiver, M., Reimer, P.J., 1993. Extended ${ }^{14} \mathrm{C}$ data base and revised CALIB $3.0{ }^{14} \mathrm{C}$ age calibration program. Radiocarbon $35,215-230$.

Thomas, R.M.E., Sparks, R.S.J., 1992. Cooling of tephra during fallout from eruption columns. Bull. Volcanol. 54, 542-553.

Vinogradov, V.I., Grigoriev, V.S., Pokrovsky, B.G., 1986. Isotope composition of oxygen and strontium in the rocks of the Kurile-Kamchatka island arc. In: Shukolyukov, Yu.A. (Ed.), Evolution of Crust-Mantle System. Nauka, Moscow, pp. 78103 (in Russian).

Vlodavets, V.I., Piip, B.I., 1957. Catalogue of the active volcanoes of Kamchatka. Bull. Volcanol. (Stancii) 25, 5-95, in Russian.

Volynets, O.N., 1979. Heterotaxitic lavas and pumices (on the problem of magma mixing). In: Sobolev, V.S. (Ed.), Problems of Deep Magmatism. Nauka, Moscow, pp. 181-197 (in Russian).

Volynets, O.N., 1994. Geochemical types, petrology and genesis of Late Cenozoic volcanic rocks from the Kurile-Kamchatka island-arc system. Int. Geol. Rev. 36 (4), 373-405.

Volynets, O.N., Scheka, S.A., Dubik Yu.M., 1978. Olivineanorthite inclusions on the volcanoes of Kamchatka and Kuriles. In: Lutz et al. (Eds.), Inclusions in Volcanic Rocks of the Kuril-Kamchatka Island Arc. Nauka, Moscow, pp. 124167 (in Russian).

Volynets, O.N., Avdeiko, G.P., Tsvetkov, A.A., Antonov, A.Yu., Markov, I.A., Phylosofova, T.M., 1990a. Mineral zoning in the Quaternary lavas of the Kurile island arc. Int. Geol. Rev. 32 (2), 128-142.

Volynets, O.N., Puzankov Yu.M., Anoshin, G.N., 1990. Geochemistry of Neogene-Quaternary volcanic series of Kamchatka. Geochemical Types of Magmatic and Metamorphic Rocks of Kamchatka. Proceedings of Institute of Geology and Geophysics, Vol. 390. Novosibirsk, pp. 73-114 (in Russian).

Wood, D.J., Banno, S., 1973. Garnet-orthopyroxene and orthopyroxene-clinopyroxene relationships in simple and complex system. Contrib. Mineral. Petrol. 42 (2), 109-124. 